\title{
RURAL ECONOMY UNDER CONDITIONS \\ OF FISCAL DECENTRALIZATION AND COVID-19 WORLD CORONAVIRUS INFECTION PANDEMIC: A CLUSTER PARADIGM
}

\section{Serhii Petrukha ${ }^{1}$}

DOI: https://doi.org/10.30525/978-9934-26-049-0-9

Abstract. The study presents the evolution of the rural economy state regulation system based on the experience of economic relations, which covered a long historical path of development. Definitely that, in Ukraine, it is relatively developed, however, in accordance with the challenges caused by a corona crisis and fiscal decentralization, individual methods of the state regulation of the rural economy require not only further improving but also evaluating for real sources of revenues of territorial communities. This stipulated the goal of research (development of theoretical provisions, elaboration of methodical and practical recommendations on studying an impact of the corona crisis and decentralization on the rural economy), enabled to build up a respective methodology based on the combination of general scientific and special methods of research of interconnections between financial capacity of local budgets - rural economy (rural development) - regulation potential from rural territorial communities as well as formulate a chain of the following conclusions. A recession caused by COVID-19 and forced sequestration of the State Budget of Ukraine has made a start of financial uncertainty and low predictability of formation of the revenue side of local budgets, having posed not only a real threat to the implementation of the second stage of the decentralization reform in Ukraine but also having cancelled out a regulatory basis for sectoral modernization of the national and local economy, having essentially braked forming institutional capacity of territorial communities to regulate the rural economy, in particular, due to reduction in budgetary appropriations for the functioning of the State Fund for Regional Development, having

\footnotetext{
${ }^{1} \mathrm{PhD}$ in Economics, Doctoral Student, Kyiv National University of Construction and Architecture, Ukraine ORCID: https://orcid.org/0000-0002-8859-0724
} 
formed a steady trend towards delaying in establishing the Fund for Development of Rural Areas. It is found that within the framework of the dual model of regulation of the rural economy at the local level, it is takes place by forming respective, as a rule, three-year programs of development of the agrarian sector of the economy, however, at the level, which still does not allow not only to ensure an expected level of local value-added of agro-products but also shape the regulation architecture ideology, from territorial communities, of the institutional composition of the rural economy, bringing, to the forefront, their potential to support the said process, which closely correlates with financial capacity. A conducted corona test for financial capacity against the background of reduction in the fiscal base of local budgets has established that the existing situation with receipts of financial resources does not allow to gain value-added from the functioning of the rural economy at the local level, having left a traditional level of regional dependence from the effectiveness of the performance of the agricultural production, which does not correlate, to a sufficient extent, with program values of stimulation of rural development, cutting them, on a priority basis, against the background of the need to improve transport connection to timely deliver medical aid to the population, be in a position to test it for the presence of a coronavirus and do future vaccination.

The scientific novelty of the results of research consists in developing the theoretical provisions as well as elaborating methodical and practical recommendations on providing enhancement of the efficiency of the state regulation of the rural economy on the basis of the developed multi-stage methods of the assessment of the state of the rural economy and regulatory potential of territorial communities including forming a specialized system of assessment indicators reflecting an impact of the corona crisis on the status of local budgets (with a focus on rural territorial communities) with a projection of the degree of importance of each its component in the system of management of changes in the rural economy.

\section{Introduction}

State regulation of the rural economy is a component, concurrently, of the agrarian, social, economic, financial, construction and territorial policies of Ukraine, allows to substantially reduce the consequences of nonequivalence in the commodity exchange of agriculture with other branches of the 
economy, provide the efficient functioning of the agrarian sector subject to the need to form a national system of sustainable development of rural areas as one of the dominants of initiating in 2014 and implementing (to this day) a decentralization reform. In the countries, where a state regulation focus is shifted from the agrarian sector of the economy to rural areas, a combination of which forms (in a simplified form) a rural economy institution, stimulation of and assistance in the territorial balancing and sustainable development of a rural area, rural territorial communities and the whole economy of rural areas of the country are carried out at much more active rates.

Toughening challenges of the external environment - a world coronavirus infection (COVID-19) pandemic, a complex geopolitical situation, loss of efficiency or full food distribution orthodox channels stop caused by government's measures of our country and Ukraine's trade partner countries allowing to stop the spread of the coronavirus, a growth, against this background, in technical barriers for export of agricultural raw materials and food products (raising the requirements to a quality of food, its environmentalization), shortage of labor in a rural area (not only because of migration traditional for our country but also because of the COVID-19 infection), growing competition of food producers in the internal market with concurrent stagnation of rural areas against the background of an insufficiently formed critical mass of the institutional and regulatory potential of local authorities - require developing and applying modern rural economy regulation methods, which must be economically reasonable and stipulating effectiveness of used tools, when intensive state support will be able to provide respective rates of increasing production volumes, exclude the cases of misuse of public funds, form the sustainable rural development environment. In addition, improved rural development regulation methods must lead to deceleration of outflow of the able-bodied population from a rural area, activation of agricultural construction (industrial and social) and their combination with local authorities' regulative capacities, which were born by the decentralization reform - to create the conditions for a forcing gain of local value-added, development of the niche agricultural production, adoption of anti-crisis measures for encountering a world coronavirus pandemic by the rural economy.

Insufficient elaboration of theoretical and practical aspects of the problem under consideration stipulates a need for in-depth research of 
the matters of the functioning of the rural economy under the conditions of decentralization, a corona crisis subject to its impact on the regulatory potential of local authorities, actualizing such kind of studies.

Matters of determination of the role of the state in developing of economic relations, in general, and in a rural area, in particular, are considered in papers of both foreign scientists - classics of the economic theory A. Wagner, J. Galbraith, F. Quesnay, J. M. Keynes, J. B. Clark, F. List, K. Marx, J. S. Mill, A. Smith, L. Thurow, and domestic researchers - A. Schlichter, A. Chukhno, I. Lukinov, A. Alymov, N. Chumachenko, P. Sabluk et al.

Theoretical foundations of the state regulation under the conditions of the strengthening of institutional systems of stimulation of the economy, industrialization (neo-industrialization), globalization, financialization and changing of a paradigm of economic goals of both the state and economic entities were reflected in papers of N. Wiener, C. Bamford, V. Geets, P. Leonenko, I. Lunina, A. Danylenko, V. Zymovets, S. Hasanov, H. Ryzhakova, P. Lulikov, S. Stetsenko, I. Yehorov, L. Deineko, B. Danylyshyn, Yu. Ivanov, T. Bohdan, V. Nebrat, O. Belorus et al., and in respect of the rural economy - in studies of T. Ostashko, Ye. Shubravska, Ye. Borodyna, Yu. Lupenko, N. Puhachov, A. Shpykuliak, M. Mohylev, V. Mesel-Veseliaka et al.

Problematics of the formation of the scientific preconditions for conducting, in Ukraine, a reform of decentralization in the system of the nano-paradigm of architecture of the budget system, sectoral stimulation, sustainable development of rural areas and clustering are considered in papers of N. Voinarenko, Ya. Zhalilo, Ye. Kuzkyn, V. Kudriashov, V. Oparyn, M. Stehnei, A. Obykhod, Yu. Shpylevoi, A. Shkuratov, T. Paliichuk, A. Vatulev, I. Liutyi, V. Fedosov, A. Lesovoi, N. Talavyr and other scientists.

Studying an impact of the world coronavirus infection pandemic on the rural economy and progress of achieving decentralization goals within the framework of rural development is considered in research of both world relevant institutions, among which a special place is held by the UN Food and Agriculture Organization, World Bank, World Food Program, and Ukrainian scientists - V. Mamchur, I. Irklyenko, K. Nazarov, M. Kropyvko, B. Dukhnytskyi, M. Hladyi et al.

Despite the availability of a wide range of methodological approaches to the grounding of efficient directions and methods of the state regulation 
of the rural economy, most of them assume concentrating efforts on specific directions that does not allow to provide achieving a synergic effect from complexity and systemacity of available tools allowing to combine national and local (at the level of territorial communities) regulation and stimulation of rural development under the conditions of the need to overcome an impact of the corona crisis on the rural economy. This circumstance predetermines a need for further development of theoretical provisions, elaboration of methodical and practical recommendations as well as rural economy development regulation tools providing symbiosis of economic, social and infrastructure-and-construction goals of agricultural and non-agricultural types of activities in rural communities established within the framework of the decentralization reform. Addressing said matters stipulated choosing a theme, setting a goal and tasks of research.

A goal of research consists in developing theoretical provisions, elaborating methodical and practical recommendations on studying an impact of the corona crisis and decentralization (in particular, reforms interconnected and stemming from it, for example, the Public Finance Management Reform Strategy for 2017-2020, the Agrarian Sector Development Strategy until 2020, the Rural Area Development Concept) on the rural economy. In accordance with the set goal, a respective research logic is formed, which determined the following tasks:

- studying an impact of anti-epidemiological measures on sectoral development of the national economy, in general, and rural economy, in particular;

- determining a need for sectoral encountering and regulatory encountering an impact of the corona crisis on the rural economy from local authorities (territorial communities);

- analyzing a budgetary architecture and composition of the system of anti-crisis regulation and corona crisis implementation of the agrarian-andconstruction vector of the national Economic Recovery project;

- diagnosing and analyzing contradictions between the composition of the rural economy and institutional-and-regulatory potential of territorial communities under the conditions of budgetary restrictions and consolidation of local budgets;

- Corona crisis measuring the functioning of the rural economy, a potential for the transition to noospheric co-development. 
The scientific novelty of the results of research consists in developing the theoretical provisions as well as elaborating methodical and practical recommendations on providing enhancement of the efficiency of the state regulation of the rural economy on the basis of multi-stage methods of the assessment of the rural economy and regulatory potential of territorial communities including forming a specialized system of assessment indicators reflecting an impact of the corona crisis on the status of local budgets (with a focus on rural territorial communities) with a projection of the degree of importance of each its component in the system of management of changes in the rural economy that allowed to:

- refine a notion of "rural development" within the system of the current paradigm of symbiosis of the national and local regulation - as stable socioeconomic development of rural areas, food production volume growth (with an focus on deep processing of agricultural raw material), growth in efficiency of agro-goods producers, achievement of complete employment of rural population (including that in non-agricultural types of economic activities) and its living standard growth, rational use of agricultural lands, provision of local food sovereignty, growth in rural construction scales;

- develop a solution tree and form hierarchic levels of regulation and stimulation of the local economy, in general, and rural economy, in particular;

- ground the priorities of functional tasks of rural territorial communities by basic direction of structural adaptation of rural development to the conditions of de-globalization or transition to noospheric co-development.

The methodological basis of research is general scientific and special methods, which were used to obtain results in accordance with the tasks of research: historical, logical, of scientific abstraction, induction and deduction, analysis and synthesis, comparative and cluster analysis, empirical generalization and aggregation, fuzzy logic and systems approach.

\section{Cluster Analysis of Inter-Influences and Inter-Dependencies of Introduction of Anti-Epidemic Measures on Sectoral Development of National Economy}

Provided that COVID-19 spreads in many counties of the world and quarantine measures are introduced, as a result of which business and economic activity rapidly declines, volumes of production reduce, and 
thus, also receipts into the state and local budgets reduce, an unemployment level grows and all this is characteristic for Ukraine as well. Introducing a quarantine by the Cabinet of Ministers of Ukraine in order to prevent the spread, in the territory of Ukraine, of the COVID-19 acute respiratory disease caused by the SARS-CoV-2 coronavirus, has adversely impacted on the carrying out of economic activity in Ukraine: the consequences provided by the quarantine have been experienced by all economic entities that complicates or makes at all impossible to render timely payouts under available credit obligations (loans).

A special role in stimulating and supporting the economy under the conditions of overcoming the consequences of COVID-19 is cast for the fiscal and monetary policy of the state having a direct and indirect impact on any spheres of economic activity of society. So, improving a budgetary policy under the conditions of fighting COVID-19, accumulating required financial-and-monetary resources, providing their weighted allocation and more effective use becomes an important task for Ukraine as a state striving to ensure a high level of economic welfare.

Quarantine measures introduced by the Government in the first quarter of 2020 to prevent the occurrence and spread of the coronavirus have had an impact on the resource provision of local self-government in the next quarters. Rates of business activity have slowed down, as, the operation, in particular, of business entities that provides receiving visitors, in particular, public catering facilities, trade and entertainment centers, other entertainment activity institutions, fitness centers, institutions of culture; the carrying out of activity on the provision of financial services, activity of financial institutions and activity on encashment and transportation of currency valuables as well as medical practice; activity on the provision of public catering services at outdoor venues etc. were prohibited.

A global spread of the virus has caused the overloading of healthcare systems and all-round socioeconomic destabilization. The International Monetary Fund forecasts declining in the world economy in 2020 by $3 \%$ [53], analysts of the Fitch international rating agency expect reduction, in 2020 , in world GDP by $1.9 \%$, while a deep recession is a baseline scenario [50]. According to information of the Ministry of Finance of Ukraine $[3 ; 18]$, forecasts for the rates of changing in real GDP of Ukraine, in 2020, are in the very wide range - from increasing by $1 \%$ to falling by $7.5 \%$. 
According to the forecast approved by the Government, real GDP will reduce, in 2020, by $4.8 \%$ [32]. The IMF forecasts a drop in the economy of Ukraine, according to the 2020 results, by $7.7 \%$, however, expects a growth in the economy, in 2021 , by $3.6 \%$ [53].

An impact of quarantine restrictions on the economy of the country can be conventionally divided into a direct and indirect impact:

direct impact - reducing in the revenue and profit of economic entities due to a rapid and complete decrease in the production and consumption of goods and services, which cannot be provided online, incurrence of expenses (losses) by economic entities under current contracts including a repayment of funds to consumers for undelivered services and goods; reducing in employment and productivity of labor caused by forced downtimes and respective placement of employees on unpaid leave; growing in prices for products and services and price volatility; reducing in tax receipts (personal income tax, single tax, corporate profit tax, VAT, tourism fee etc.);

indirect impact - declining in business activity and investments, increasing in unemployment and social payments and shadowing of the economy (business shifting into the informal sector of the economy), reducing in business chains and transferring business processes into a digital format (online), reducing in revenues of employees, spending of savings; increasing in social payments (unemployment benefit); worsening of the fiscal balance and narrowing of the private sector of the economy.

For the economy, basic consequences caused by restrictions in connection with fighting COVID-19, include [2; 44; 47]: reducing in export and import; cancelling investment projects; changing in the structure of industries of the economy; reducing in allied business suppliers - chain reducing in value added in the sphere of services; temporary downtimes and/or personnel dismissal, private sector narrowing; demand contraction, able-bodied populations' deskilling; increasing in outsourcing; transferring the provision of services into a digital format (business digitalization); increasing in a share of online consumption of digital products and services; growing in the state budget deficit; increasing in state debt service expenditures; declining in financial capacity of local budgets; reducing in working capital of business and savings of households; transforming business chains; increasing in a shadow share of the economy; declining in competitiveness of economic entities; growing in population poverty and 
inequality; inflating costs; business model changing; dropping in prices for products and services in the long term.

\section{Priority Directions of Modernization of System of State Regulation of Sectoral Adaptation of Economy of Ukraine to Corona Crisis Conditions}

There are many various state regulation components, on the efficiency of the use of which a level of welfare of society and prospects of further economic development of the country depend. A weighty role among said components is cast for the budgetary policy of the state as exactly it determines the directions of the functioning of finances, cash flows, enables to provide a targeted use of financial resources, implement basic priority goals of economic development etc.

A budgetary policy is a weighty element of the financial policy and one of the key tools of the implementation of the economic and social policy of the state. Exactly this policy personifies a place and role of the state in the regulation of socioeconomic processes and the provision of economic growth. Therefore, "the successfulness of the implementation of managerial functions of the state in all spheres of its influence - social, economic, ecological etc. - ultimately depends on the optimality and efficiency of the establishment of the budget process" [10; 13-14; 52].

A budgetary policy is closely connected to the economy. In particular, the policy is able to influence the economy both positively and negatively. In this connection, the state, forming a budgetary policy, must comply with such basic conditions: taking into account the requirements of all objective economic laws and regularities of development of society; studying and taking into account the previous experience of economic, financial and budgetary development; studying and taking into account the experience of other countries; taking into account a specific stage of development of society, features of the internal and international situation; complying with a comprehensive approach to the elaboration and implementation of measures of the budgetary policy, a policy in the field of finances, price setting, loan, pay etc. [7; 9].

A budgetary policy affects the efficiency of the economic management of enterprises and organizations applying such budget tools: state procurement, taxes and transfers, interest rates, budget control, penal sanctions, budget investments, budget loans, state guarantees, state subsidies. 
Basic tasks of the budgetary policy are: 1) assistance in achieving stable rates of economic growth in the country, optimizing economic dynamics; 2) efficient distribution and optimal use of public expenditures; 3 ) ensuring of responsibility of all budget process subjects for fulfilling assumed obligations; 4) balancing of budgets at all levels; 5) strict and steady compliance with the norms of budget legislation by budget process subjects $[1 ; 22]$.

A need to provide coordinated management of preparedness for and response to the spread of the COVID-19 acute respiratory disease has conditioned the necessity to review the priorities of the budgetary policy and further implementation of mechanisms of emergency situation management in healthcare involving relevant line ministries such as the ministry of health, foreign affairs, finance, economy, education, social protection, development of communities and territories as well as other anti-crisis management bodies.

In order to prevent the occurrence and spread of the COVID-19 acute respiratory disease, a need emerged to introduce changes to the priorities of the budgetary policy of Ukraine - the activity of state bodies of power and management was reviewed and adjusted in terms of the formation, fulfillment and regulation of the financial plan of the state.

The Ministry of Finance of Ukraine as the main body within the system of the central bodies of executive power providing the formation and implementing the state budgetary policy (including that in the sphere of inter-budgetary relations and local budgets), subject to overall uncertainty in respect of the time periods of overcoming the COVID-19 pandemic and scales of its impact on the world economy and, in particular, the economy of Ukraine, will coordinate a budget process in 2020, subject to the impact of the coronavirus in the short- and long-term period [51].

Under the conditions of volatility of the socioeconomic situation in Ukraine, in particular, in connection with introduction of a number of measures for preventing the occurrence and spread of the coronavirus disease, a need arose to introduce amendments to the legislation of Ukraine, in order to reduce an adverse impact of the spread of the COVID-19 coronavirus, ensure the fulfilment of the state's functions.

A business activity decline caused by the spread of the coronavirus disease has conditioned an urgent need for the state to take measures to support taxpayers. 
On 17 March 2020, the Verkhovna Rada of Ukraine adopted the Law of Ukraine "On Introduction of Amendments to Some Legislative Acts of Ukraine Aimed at Preventing the Occurrence and Spread of the Coronavirus Disease (COVID-19)" [26] providing a simplified procedure for procurement of goods, works and services for the purposes of fighting COVID-19; VAT exemption for transactions of importing into the customs territory of Ukraine for medicines, medical products and/or medical equipment needed to carry out measures aimed at preventing the occurrence and spread, localization and liquidation of outbreaks, epidemics and pandemics of COVID-19.

According to data of the State Treasury Service of Ukraine, by 28 May 2020 inclusive, the payments were made - from the budgets of all levels for the amount of UAH $2.62 \mathrm{~B}$, of which: UAH $658 \mathrm{M}$ - from the state budget and UAH $1.965 \mathrm{~B}$ - from local budgets. The total amount of registered budget obligations under all procurements of goods and services for fighting COVID-19 is over UAH 3.4 B (UAH $934 \mathrm{M}$ - state budget, UAH 2.484 M - local budgets).

In addition, the parliament adopted the resolution (Laws No 533-IX and No 540-IX) [29-30] to: exempt, for the period from 1 March to 31 September 2020, from imposing a land charge, a tax on immovable property, further it is provided not to use penal sanctions for violations of tax legislation; put a moratorium on conducting documentary and actual inspections; increase the maximum amount of income allowing to pay a single tax (group I - from UAH $300 \mathrm{~K}$ to UAH $1 \mathrm{M}$; group II - from UAH 1.5 M to UAH $5 \mathrm{M}$; group III - from UAH $5 \mathrm{M}$ to UAH $7 \mathrm{M}$ ); increase a list of expenses, which may be included to obtain a tax allowance; postpone the submission of the annual asset and income declaration for 2019 (extending the deadlines from 1 May to 1 July 2020).

The Government adopted the resolution on business support under the quarantine conditions by improving the mechanism of the "Affordable 5-7-9\% Credits" State Program, extending its functionality and a circle of entrepreneurs who will be able to use it. For this purpose, on 18 March 2020, the Cabinet of Ministers of Ukraine adopted the Resolution "On Introduction of Amendments to the Procedure for the Provision of State Support to Micro-Business and Small Business Entities" [31].

In preparation of said amendments, an urgent need arose to supplement them by the provisions aimed at preventing the spread of the coronavirus disease in Ukraine and overcoming its consequences. 
In terms of giving new opportunities to entrepreneurs and improving the "Affordable 5-7-9\% Credits" Program itself, it is provided to:

1) increase the maximum credit amount from UAH 1.5 to $2 \mathrm{M}$;

2) extend the investment purposes, for which credits may be granted: acquisition of non-residential real estate without the right to transfer such real estate for paid or free use to third parties; acquisition of intellectual property items under commercial concession contracts (franchising) associated with the implementation of the investment project by a business entity; replenishment of current assets of business entities in the amount not exceeding $25 \%$ of the total value of the investment project financed from the credit funds;

3 ) review a credit interest rate calculation;

4) increase, up to $35 \%$, a level of the maximum amount of the payment under the guarantee of the Entrepreneurship Development Fund with a relevant increase of the allowed level of the portion of the troubled debt under credits granted to newly-established business entities, up to $25 \%$.

In terms of changes intended to prevent the spread of the COVID19 coronavirus disease and overcome its consequences, it refers, in particular, to:

1) the extension of the purposes, for which the financial state assistance is given, by anti-crisis measures, and the purposes, for which credits may be granted under this procedure: investment purposes associated with carrying out business activities by a business entity on the production of medicines and/or medical products and/or medical equipment; financing of the working capital of business entities carrying out business activities on the provision, to the population, of social-and-medical services and/ or social-and-domestic services (including care of patients, food product delivery etc.), to cover expenses of the business entity for payment of wages of employees, rent, utility services etc., and to the extent that such financing will result in preserving or gaining jobs of the business entity;

2) setting a deadline, until which business entities may apply for the state assistance for anti-crisis measures, until 1 September 2020;

3 ) setting the maximum credit amount: up to UAH $3 \mathrm{M}$ for business entities, which will introduce economic activities on the production of medicines and/or medical products and/or medical equipment; up to UAH $1 \mathrm{M}$, if a credit is granted for the financing of the working capital of the business entity in certain cases; 
4) reduction in expenses for payment of the base interest rate under credits of business entities carrying out business activities on the production of medicines and/or medical products and/or medical equipment;

5) inclusion of credits, which will be granted for anti-crisis measures, into the authorized banks' credit portfolio, under which a state guarantee is provided in the amount of $80 \%$ of the principal debt amount.

As of 09.06.2020, 605 credits were granted for the amount of UAH 381.05 M [25]. Further, partner banks continue to receive applications for new program tools implemented by the Government during the validity of quarantine measures for countering the COVID-19 pandemic (re-financing, working, investment credits for medical equipment manufacturers).

On 13 April 2020, by introducing an amendment to the State Budget of Ukraine for 2020 [28], the Fund for Fighting the COVID-19 Acute Respiratory Disease and Its Consequences was established in the amount of UAH 64.7 B.

The Fund for Fighting the COVID-19 Acute Respiratory Disease and its Consequences is a fund within the state budget formed to prevent adverse consequences of crisis phenomena in connection with the occurrence and spread of the COVID-19 acute respiratory disease; increase the efficiency of activities of state bodies, local bodies of self-government; ensure macroeconomic stability in Ukraine [23]. The time period for the functioning of the fund equals to the time of validity of the quarantine and the next 30 days after its cancellation.

By the resolution and in the procedure set by the Cabinet of Ministers of Ukraine, upon consultation with the Budget Committee of the Verkhovna Rada of Ukraine, the funds of the Fund will be channeled for [28]:

- measures aimed to prevent the occurrence and spread, localization and liquidation of outbreaks, epidemics and pandemics of the COVID-19 acute respiratory disease, in particular, for procurement of goods, works and services, needed for carrying out said measures including procurement of medical services under the program of state guarantees of medical service of the population;

- additional extra payments to wages for medical and other workers directly involved in works on the liquidation of the COVID-19 acute respiratory disease as well as extra payments to wages for separate categories of workers ensuring life activities of the population for the period of 
carrying out measures aimed at preventing the occurrence and spread, localization and liquidation of outbreaks, epidemics and pandemics of the COVID-19 acute respiratory disease;

- granting monetary assistance to citizens, in particular, to aged persons, in connection with adverse consequences of the spread, in the territory of Ukraine, of the COVID-19 acute respiratory disease;

- granting a one-time monetary aid to family members of medical and other workers of the healthcare institutions, who succumbed (died of) to the COVID-19 acute respiratory disease that is associated with the fulfillment of works on the liquidation of such disease, in the procedure and amounts set by the Government;

- granting a transfer to the Pension Fund of Ukraine;

- granting a financial assistance, on a returnable or non-returnable basis, to the Social Insurance Fund of Ukraine and Fund of Obligatory State Social Insurance of Ukraine in Case of Unemployment, on a returnable or non-returnable basis;

- replenishment of the reserve fund of the state budget;

- resumption of expenditures of the state budget (including transfers to local budgets) and granting credits from the state budget under budget programs cut in connection with the setting of the fund.

It is provided that ministries, oblast, Kyiv City State Administrations and other bodies of state power will submit, to the Cabinet of Ministers of Ukraine, applications for allocations of funds, in which they will state the area of channeling the resources of the fund and their amount, key spending units of budget funds (KSUBF), the terms of allocation of funds, proposals for the terms and guaranties of repayment of such funds, information on an opportunity of financial security for respective measures from other sources. The application should also be attached by financial and economic calculations and feasibility of the required amount of funds. KSUBF obliges to submit, up to the 5th day of the month following the accounting month, to the Budget Committee of the Verkhovna Rada of Ukraine, Cabinet of Ministers of Ukraine and Ministry of Finance of Ukraine, the information on the use of budgetary funds, their repayment to the state budget. The latter is assigned to be in charge of the monitoring of information on the use of budgetary funds.

According to information of the Ministry of Finance of Ukraine [20], as of 15 June 2020, the Government has adopted the resolution (subject 
to protocol resolutions) on allocation of UAH 36.1 B from the Fund of Fighting COVID-19: according to regulations of the Government, UAH 18.7 B are allocated, an opportunity is provided by protocol resolutions to allocate additional UAH $17.4 \mathrm{~B}$ from the Fund, of which nearly UAH $9 \mathrm{~B}$ - for social protection and unemployment assistance, UAH 1.6 B for support of children of individuals-entrepreneurs, UAH $3 \mathrm{~B}$ - for healthcare. As of 15 June, UAH 1.8 B of the Fund were actually used.

Further, Law No 553-IX [28] provides that, temporarily, from the effective date of the Law until 1 January 2021, some norms of the Budget Code of Ukraine will not be applied, in particular, for the implementation of mid-term budget planning, namely, its suspension; budgetary policy on local budgets and inter-budgetary relations must include a directivity on support of financial capacity of bodies of local self-government.

Concurrently, the Ministry of Finance informed [18] of further implementation of mid-term budget planning in Ukraine, which must ensure a strategic approach to establishing priority measures and respective allocation of limited resources.

On 27 May 2020, the President of Ukraine signed the Law on Additional Support of Taxpayers for the Period of Implementation of Measures Aimed at Preventing the Occurrence and Spread of the Coronavirus disease (COVID-19) No 591-IX [30].

Law No 591-IX provides extension of validity of tax privileges and simplified administrative procedures by the end of the quarantine, in particular:

- extension of the period of non-application of penal sanctions for tax legislation violations from 1 September to the last calendar day of the month, in which the government will announce the end of effect of the quarantine;

- extension of the period of non-imposition of penalty;

- exemption form payment of a single social contribution for entrepreneurs until 31 May 2020;

- extension of a moratorium on conducting documentary and actual inspections;

- compensation from the budget for the tax on personal incomes withheld from incomes as extra payments to wages of medical workers directly employed in the liquidation of the epidemic; 
- non-inclusion, into the total monthly (annual) taxed income of a personal income tax payer, of incomes in the form of underemployment assistance (for the quarantine period), etc.

At the Government's meeting on 27 May, the State Program of Stimulation of Economy to Overcome Adverse Consequences Caused by COVID-19, was presented [49]. The purpose of the Program is to implement a comprehensive system of measures for stabilization and sustainable development of the economy of Ukraine, increase the employment of the population by keeping existing and stimulating the creation of new jobs.

The Program includes three sections. Section 1 provides short-term initiatives in response to COVID-19: guaranteeing safe functioning of the economy; support for industries of the economy and protection of their goods, works and/or services against import alternatives supplied into the territory of Ukraine, subject to international treaties and obligations of Ukraine.

In support of the economy, measures were developed for six sectors: industry, agriculture, energy industry, transport and infrastructure, information and communication technologies, service sector (trade, hotel and restaurant business, education, creative industries, personal services). Support for industries of the economy must be accompanied by implementing general functional measures, which will enhance sectoral initiatives. Functional directions include support for small and medium business, stimulation of international trade, attraction of investments, development of innovations, labor market development, reasonable regulation of economic activities.

\section{Budget Regulation of Anti-Crisis Measures \\ for Overcoming COVID-19 Consequences} and Financial-and-Institutional Potential of the Economic Recovery National Project: An Agrarian-Construction Vector

Law No 553-IX [28] introduced a number of amendments to the 2020 State Budget:

- revenues are decreased by UAH $119.7 \mathrm{~B}$, or by $10.9 \%$, including: general fund revenues - by UAH $119.7 \mathrm{~B}$, or by $12.5 \%$; special fund revenues are increased by UAH $16.3 \mathrm{M}$, or by $0.01 \%$;

- budget expenditures are increased by UAH $82.4 \mathrm{~B}$, or by $6.9 \%$, including: general fund expenditures - by UAH $82.4 \mathrm{~B}$, or by $7.8 \%$, special fund expenditures - by UAH $13.2 \mathrm{M}$, or by $0.01 \%$; 
- granting credits from the state budget is decreased by UAH $20.0 \mathrm{M}$, including: granting loans from the general fund is decreased by UAH $34.7 \mathrm{M}$, or by $2.0 \%$; granting loans from the special fund is increased by UAH $14.6 \mathrm{M}$, or by $0.1 \%$;

- the maximum budget deficit amount is increased by UAH $202.1 \mathrm{~B}$, or threefold, including: the maximum amount of the general fund deficit is increased by UAH $202.1 \mathrm{~B}$, or fourfold; the maximum amount of the special fund deficit remained unchanged - at the level of UAH 23.9 B.

Minister of Finance commented the approval of amendments to the 2020 State Budget by the Verkhovna Rada of Ukraine [19]: "We have put, into this budget, the resource from international financial organizations, incl. the IMF's direct budget support. Support from our international partners is very important because it makes it possible for us to fully finance all required expenditures, in the first turn, wages of doctors, social protection, expenditures for infrastructure. We expect from the parliament positive voting also for the so-called banking draft law, which will accelerate the receipt of the IMF's assistance".

On 9 June 2020, the Executive Board of the IMF made a decision on the approval of the 18-month Stand-by Program and allocation of the first USD 2.1 B disbursement. The Stand-by Program focused on the key task supporting macroeconomic and financial stability - will cover, inter alia, such spheres: fiscal policy, monetary policy, financial sector policy, energy policy and anti-corruption policy. Implementing the provisions of the Memorandum will afford to receive, by the end of the program, the remaining funds from the IMF (USD 2.9 B), which must ensure macroeconomic and financial stability. The availability of such program afforded to receive the second tranche under the fourth EU macro-financial assistance program of EUR $500 \mathrm{M}$ [17].

In terms of fulfilling the state budget indicators for the quarantine period, in April 2020, the general fund of the state budget received UAH 90.9 B, of which nearly UAH 43 B - from the National Bank of Ukraine [42]. State budget revenues inclusive of inter-budgetary transfers, for January - April 2020 , amounted to UAH $314,847.28 \mathrm{M}$ that is by UAH $7,716.84 \mathrm{M}$, or $2.39 \%$ less than for the same period of 2019. Tax receipts for January April 2020 were equal to UAH $239,570.27 \mathrm{M}$, that is by UAH 1,976.92 M or $2.7 \%$, less than for January - April 2019 (Figure 1). 


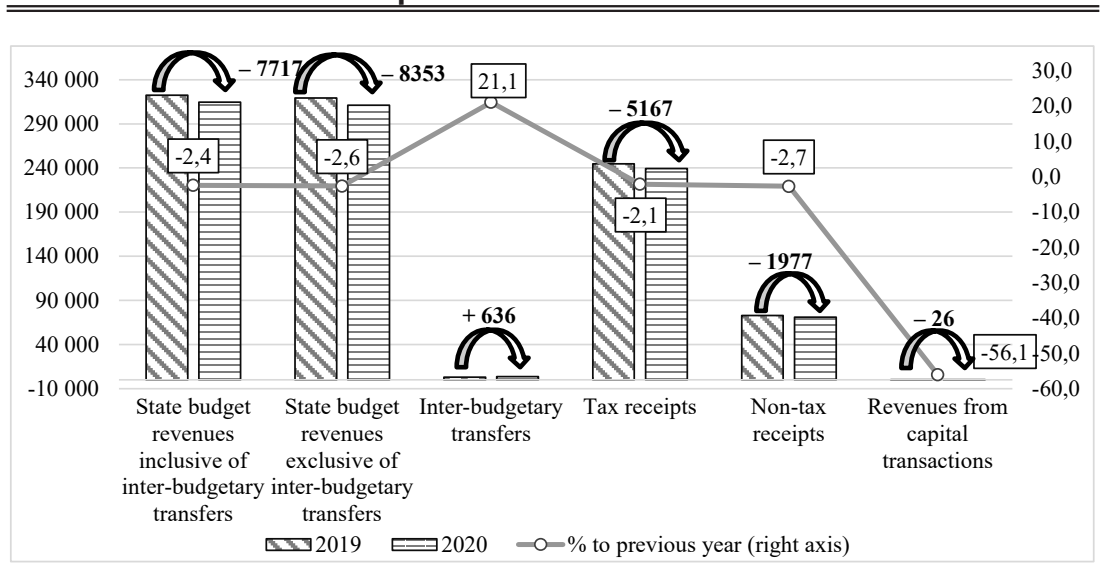

\section{Figure 1. State Budget Receipts Amounts Comparison for January - April 2020 and the Same Period of the Previous Year}

Source: Calculated and compiled on the basis of data of the State Treasury Service of Ukraine [12]

In April 2020, the state budget received [12]: UAH $8.5 \mathrm{~B}$ of personal income tax and military levy; UAH 7.7 B of value-added tax (balance, VAT refund amounted to UAH 12 B); UAH 5.9 B of excise duty on goods produced in Ukraine; UAH 19.6 B of customs payments.

For January - April 2020, the state budget received:

- UAH 36.624.56 M of personal income tax and levy, that is by UAH $3,579.22 \mathrm{M}$, or $10.83 \%$ more than for the same period of 2019 ;

- UAH 35,451.05 $\mathrm{M}$ of corporate profit tax, that is by $4,792.31 \mathrm{M}$, or $15.63 \%$ more than in 2019 (Figure 2).

For January - April 2020, social expenditures, expenditures on defense, servicing the debt and grants to local budgets are fully financed according to the breakdown on the basis of payment orders. So, according to operating data of the State Treasury Service, the expenditures of the general fund of the state budget amounted, for 4 months of 2020, to UAH $308.9 \mathrm{~B}$, or $87.5 \%$ of the relevant breakdown for the accounting period.

For January - April 2020, actual state borrowings to the general fund of the state budget amounted to UAH $108 \mathrm{~B}$, or $84.1 \%$ of the plan for this period. In total, for the financing of the state budget it was attracted from the placement of DGBs UAH 73.8 B (97\% of the plan), incl. from the issue of 


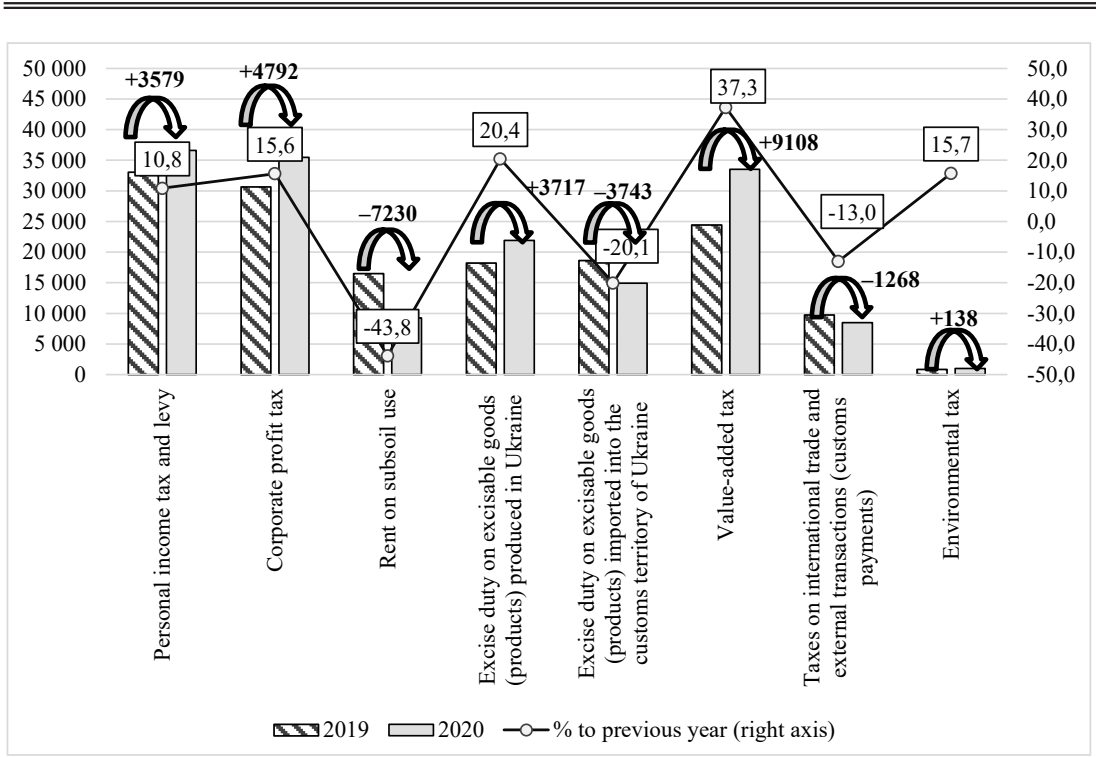

Figure 2. Basic State Budget Receipts Amounts

for January - April 2020 and the Same Period of the Previous Year

Source: Calculated and compiled on the basis of data of the State Treasury Service of Ukraine [12]

DGB's in foreign currency - UAH 41.3 B (USD 1.2 B and EUR 0.3 B). From external sources, it was attracted UAH $34.2 \mathrm{~B}$ (66\% of the plan), in particular, UAH 33.9 B by placing 10-year Eurobonds for the amount of EUR 1.25 B at $4.375 \%$ per annum. In this case, payments form the state debt redemption amounted, for January - April 2020, nearly UAH 71.3 B (81.8\% of the plan), payments for servicing - UAH $41.1 \mathrm{~B}$ ( $94.2 \%$ of the plan).

Declining in business activities caused by implementing quarantine measures aimed at preventing the spread, in the territory of Ukraine, of the COVID-19 acute respiratory disease has had an adverse impact on the fulfillment of the revenue component of the state budget. A monthly breakdown of revenues in the general fund of the state budget was fulfilled at $84.3 \%$, based on the results of January-April 2020 - at $86.1 \%$. Based on the results of January - April of the current year, the state budget was fulfilled with a deficit in the amount of UAH $23.5 \mathrm{~B}$, incl. the general 
fund - with a deficit in the amount of UAH $33 \mathrm{~B}$, that meets the budget indicators [42].

In May 2020, it has been started to mitigate the quarantine measures, aimed at preventing the occurrence and spread of the coronavirus infection, that will result in improving the economic situation in the country.

According to operating data of the State Treasury Service [12], for January - May, the state budget revenues inclusive of transfers amounted to UAH $388.3 \mathrm{~B}$, that is by UAH $38.5 \mathrm{~B}$, or $9.1 \%$ less that in the same period of 2019; tax receipts were equal to UAH $306.0 \mathrm{~B}$ that is by UAH $16.9 \mathrm{~B}$, or by 5.24\% less than in 2019 (Figure 3). Subject to non-fulfillment of the revenue breakdown, which took place in January - May 2020 (86.1\%), the revenue breakdown based on the results of January - May for the general fund of the state budget was fulfilled, in general, at $88.4 \%$.

For January - May 2020, among basic budget-forming taxes and levies, positive dynamics was shown by personal income tax and levy (military levy) $(+7.49 \%)$, corporate profit tax $(+6.92 \%)$, excise duty on excisable goods produced in Ukraine $(+18.43 \%)$, value-added tax $(+32.12 \%)$. Receipts of the rent for subsoil use, for January - May 2020, as compared to the same period of 2019 , reduced by $43.48 \%$, of excise duty on excisable goods imported into the customs territory of Ukraine - by $19.49 \%$, of taxes

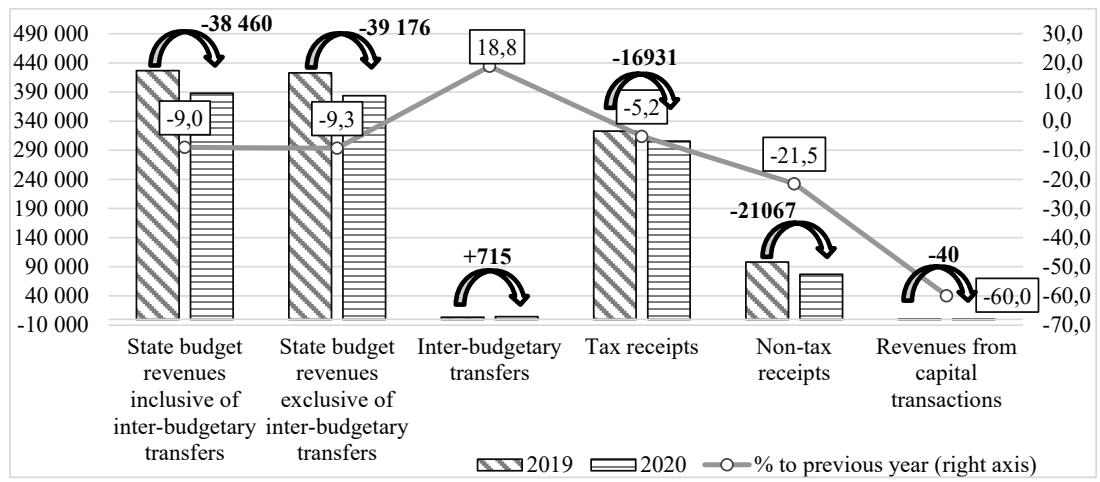

Figure 3. State Budget Receipts Amounts Comparison for January - May 2020 and the Same Period of the Previous Year Source: Calculated and compiled on the basis of data of the State Treasury Service of Ukraine [12] 
on international trade and external transactions (customs payments) by $14.28 \%$, of environmental tax - by $13.42 \%$ (Figure 4 ).

For January - June 2020, social expenditures, expenditures on defense, debt servicing and grants to local budgets were fully financed according to the breakdown on the basis of payment orders. So, the expenditures in the general fund of the state budget for 5months of 2020 amounted to UAH $392.8 \mathrm{~B}$, or $83.4 \%$ of the breakdown for the accounting period.

Based on the results of January - June of the current year, the state budget was fulfilled with a deficit in the amount of UAH $47.8 \mathrm{~B}$, including the general fund - with a deficit in the amount of UAH $52.2 \mathrm{~B}$, that is within the limits of the budget indicator planned for this period.

For January - June 2020, actual state borrowings to the general fund of the state budget amounted to UAH $160.9 \mathrm{~B}$, or $69.9 \%$ of the borrowings planned for this period.

In total, for the financing of the state budget, from the placement of DGBs, it was attracted UAH $125.3 \mathrm{~B}$ (100\% of the plan), incl., from the issue of DGBs in the foreign currency - UAH 51.1 B (USD 1.6 B and

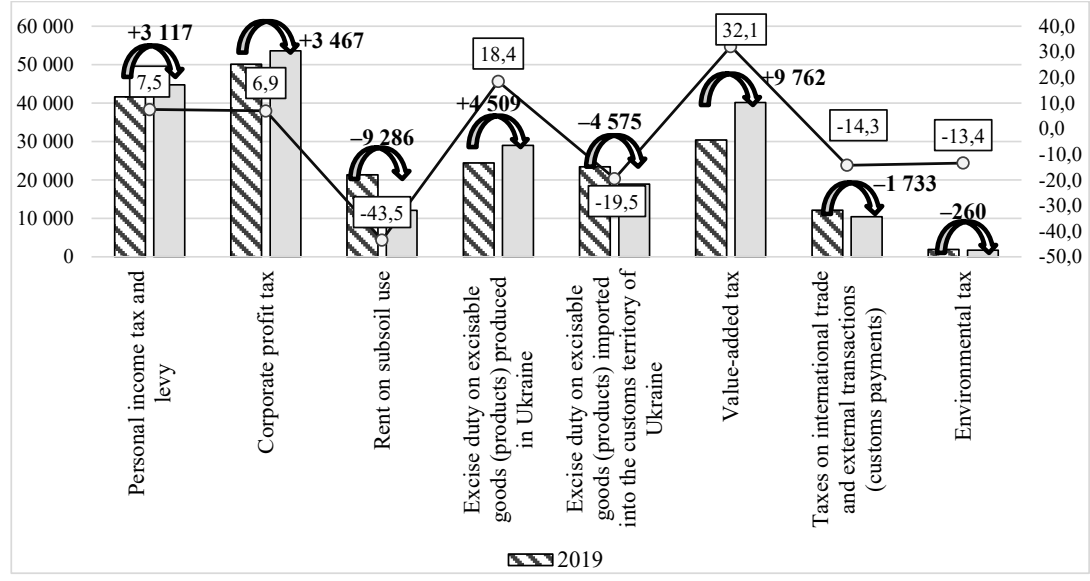

Figure 4. Basic State Budget Receipts Amounts Comparison for January - May 2020 and the Same Period of the Previous Year Source: Calculated and compiled on the basis of data of the State Treasury Service of Ukraine [12] 
EUR 0.3 B). From external sources, it was attracted UAH 35.6 B (33.9\% of the plan), in particular, UAH 33.9 B by placing 10-year Eurobonds for the amount of EUR $1.25 \mathrm{~B}$ at $4.375 \%$ per annum and UAH $1.350 \mathrm{~B}$ (USD $50.0 \mathrm{M}$ ) - receipt of the loan funds from the IBRD within the Social Assistance System Modernization Project in Ukraine. In this case, the payments for the state debt redemption were equal, for January - June 2020, to UAH $114.6 \mathrm{~B}(84.9 \%$ of the plan), payments for servicing - UAH $53.8 \mathrm{~B}$ (90.7\% of the plan) [43].

For January - June 2020, state budget revenues amounted to UAH $519.4 \mathrm{~B}$, that is by UAH $2.47 \%$ less than in 2019 . It was received UAH $360.4 \mathrm{~B}$ that is by $4.55 \%$ less than in 2019 . Revenues from capital transactions decreased by $62.97 \%$ (Figure 5 ).

Basic payments, from which the state budget was filled for January June 2020, were, in particular: personal income tax and levy (military levy) (UAH 54.3 B), corporate profit tax (UAH 54.3 B), value-added tax (UAH 48.7 B) etc. (Figure 6).

Based on the results of January - June 2020, the breakdown of revenues in the general fund of the state budget was fulfilled at the level of $92.1 \%$. For January - June 2020, social expenditures, expenditures on defense, debt servicing and grants to local budgets were fully financed according

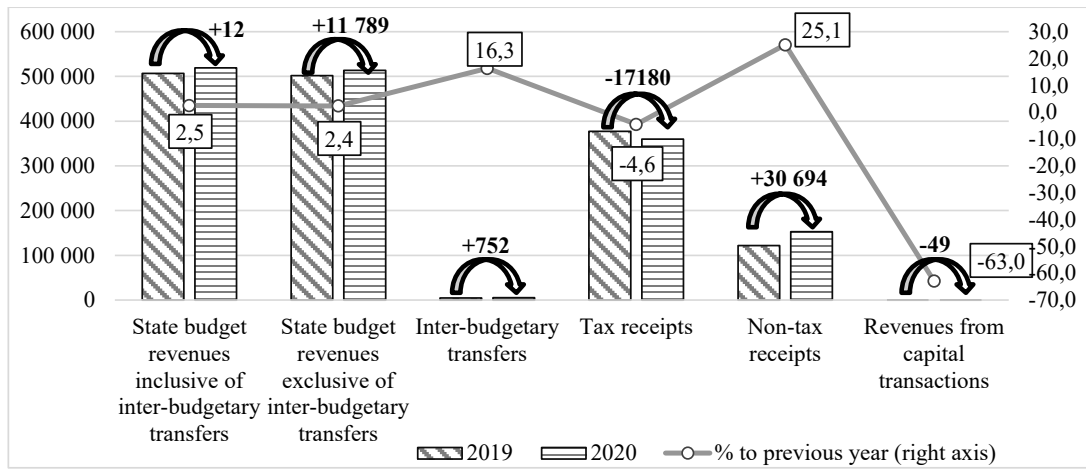

Figure 5. State Budget Receipts Amounts Comparison for January - June 2020 and the Same Period of the Previous Year Source: Calculated and compiled on the basis of data of the State Treasury Service of Ukraine [12] 


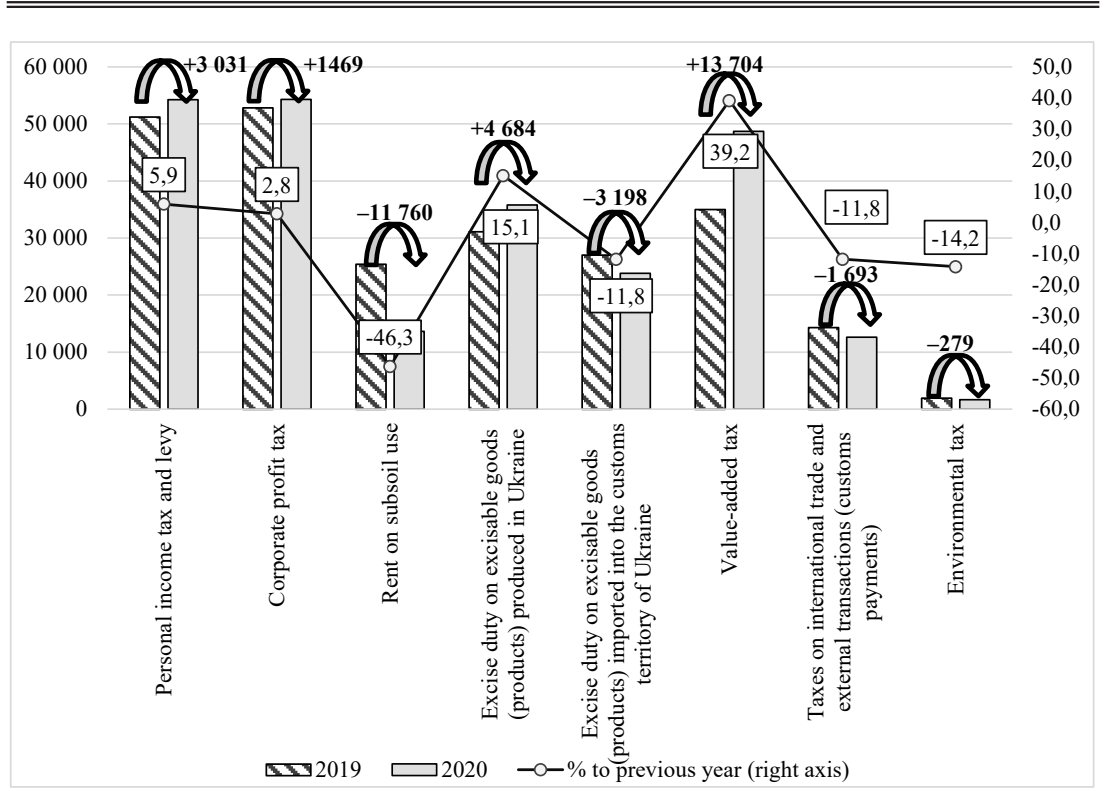

Figure 6. Basic State Budget Receipts Amounts Comparison for January - June 2020 and the Same Period of the Previous Year Source: Calculated and compiled on the basis of data of the State Treasury Service of Ukraine [12]

to the breakdown on the basis of payment orders. So, the expenditures in the general fund of the state budget amounted, for January - June 2020, to UAH $479.6 \mathrm{~B}$, or $90.4 \%$ of the breakdown for the accounting period [4].

Based on the results of 6 months of the current year, the state budget was fulfilled with a deficit in the amount of UAH $16.7 \mathrm{~B}$, including, the general fund - with a deficit in the amount of UAH 27.9 B, when the breakdown of the general fund for the accounting period amounted to UAH 42.1 B [4].

Actual state borrowings to the general fund of the state budget for January - June 2020 amounted to UAH 259.5 B, or $99.9 \%$ of planned borrowings for this period. In total, for the financing of the state budget, from the placement of DGBs, it was attracted UAH $153.6 \mathrm{~B}(99.9 \%$ of the plan), incl. from the issue of DGBs in the foreign currency - UAH 61.7 B (USD 1.6 B and EUR 0.3 B). In this case, the payments for the state debt 
redemption for January - June 2020 amounted to UAH 156.2 B (99.7\% of the plan), the payments for servicing - UAH $61.4 \mathrm{~B}$ (89.7\% of the plan) [4].

Analyzing monthly receipts of the state budget during quarter 2, 2020, shows that revenues of the state budget inclusive of inter-budgetary transfers in April and May 2020 were lower than in respective months of 2019, a significant decline in revenues was observed in May. The resumption of the 2019 dynamics began to be observed in June only (Figure 7).

Among basic trends during the second quarter, the following ones should be noted in terms of taxes and levies: receipts of personal income tax and levy (military levy) in April 2020 amounted to UAH 8,503.0 M, or by $5.27 \%$ less than in the previous year, in May 2020 - UAH 8,121.36 M, or by $5.38 \%$ less than in 2019, and only in June 2020 tax receipts have almost become equal to the indicators of the previous year:

- corporate profit tax receipts significantly decreased in June 2020 by $73.34 \%$ as compared with June 2019 ;

- receipts of rent on subsoil use also significantly reduced in June 2020 and were equal just to UAH $1,593.76 \mathrm{M}$, or by $60.82 \%$ less than in June 2019;

- environmental tax receipts in April 2020 amounted to UAH $39.30 \mathrm{M}$, or by $32.69 \%$ less than in 2019; in April 2020,
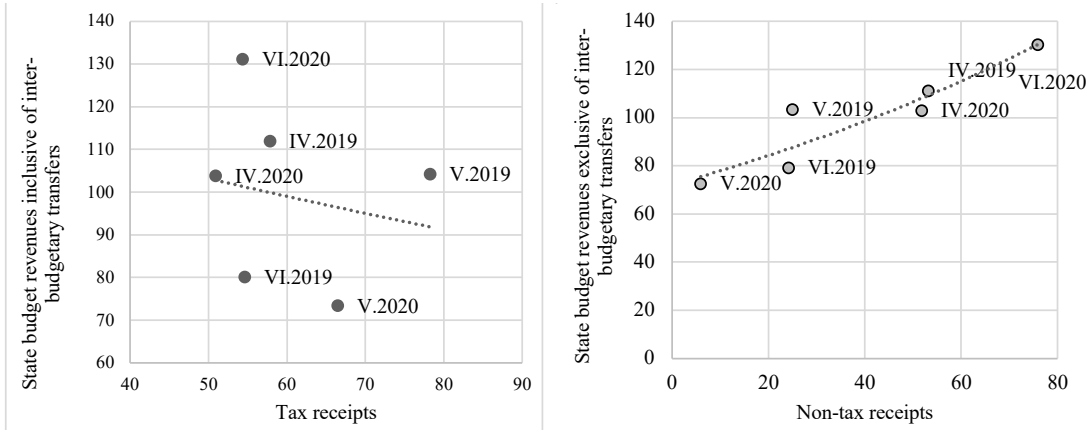

Figure 7. State Budget Monthly Receipts Dynamics During April - June 2019 and 2020, UAH M

Source: Calculated and compiled on the basis of data of the State Treasury Service of Ukraine [12] 
UAH $658.24 \mathrm{M}$ of environmental tax were received, or by $37.72 \%$, less than in 2019 , and in June the receipts of this tax were equal to UAH $4.48 \mathrm{M}$, or by $80.93 \%$ less than in June 2019 (Figure 8 ).

The breakdown of personal income tax and levy (military levy) is overfulfilled by UAH $0.1 \mathrm{~B}$, the indicator of the rent on subsoil use was fulfilled at $114.7 \%$ (over-fulfillment is UAH $0,3 \mathrm{~B}$ ), the breakdown of excise duty is over-fulfilled by UAH $1,1 \mathrm{~B}$, or by $21.4 \%$ (predominantly, from tobacco duty receipts), the breakdown of value-added tax was fulfilled at $99.8 \%$, shortfalls of corporate profit tax amounted to UAH $0.1 \mathrm{~B}$ (underfulfillment - UAH 0.5 B, the breakdown was fulfilled at 97.2\%).

Under the fourth EU macro-financial (loan) program, Ukraine received from the European Commission the second tranche in the nominal amount of EUR $500 \mathrm{M}$. The money will arrive as a loan at $0.125 \%$ per annum with a repayment date until 10.06.2035. Received funds will be used to finance state budget expenditures and assist to reduce the external financial pressure on Ukraine and improve the payment balance of the state. Given the need for appropriate funding of measures to overcome the adverse consequences

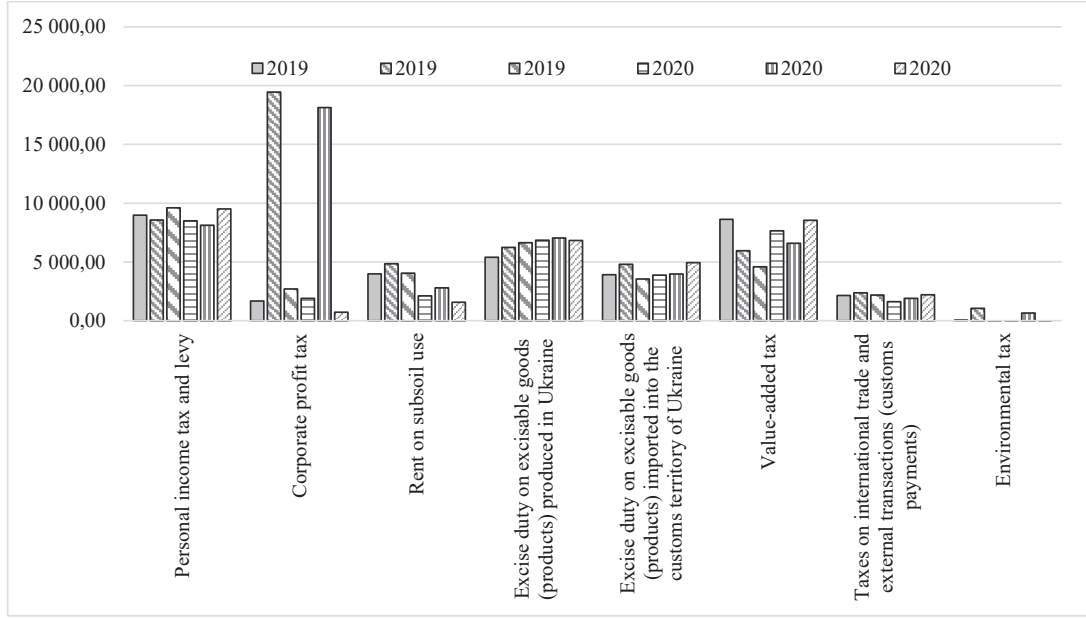

Figure 8. State Budget Basic Monthly Receipts Dynamics During April - June 2019 and 2020, UAH M

Source: Calculated and compiled on the basis of data of the State Treasury Service of Ukraine [12] 
of the spread of the COVID-19 acute respiratory disease, the receipt of said funds will assist to maintain financial stability in Ukraine [46].

Further, Ukraine has started implementing the Accelerating Private Investment in Agriculture Program. A loan agreement within the relevant project was made on 27 August 2019 with the International Bank for Reconstruction and Development. The loan amount is USD $200 \mathrm{M}$. The implementation of the Accelerating Private Investment in Agriculture of Ukraine Program will afford Ukraine to mitigate individual restrictions on the path to growth of the participation of the private sector, in particular, small and medium businesses in the agricultural market of factors of production and the product market of Ukraine [45].

Ukraine will receive USD $500 \mathrm{M}$ from the International Bank for Reconstruction and Development to support the First Economic Recovery Development Policy Loan Project. The World Bank's Board of Executive Directors adopted the respective decision on 26 June 2020 [16]. This is the first project of the series of loans in support of the development policy for the total amount of USD $700 \mathrm{M}$ that supports efforts of the Government of Ukraine to implement reforms in such main directions:

- enhancing de-monopolization and anti-corruption institutions, in particular, by unbundling property in gas industry, improving the legal framework for concessions and strengthening anti-corruption institutions;

- strengthening the land market and credit market by creating a transparent agricultural land market with relevant protection guarantees, enhancing a mechanism for resolving non-performing loans and supervising over non-bank financial institutions;

- bolstering the social support system by increasing the amount of pension payments.

\section{Local Budgets and Institutional Potential of Territorial Communities Before Regulation and Management of Changes in Rural Economy}

Amendments to the budget and tax legislation introduced in the first quarter of 2020 on preventing adverse consequences of crisis phenomena in connection with the occurrence and spread of the COVID-19 acute respiratory disease as well as the impact of the implementation of quarantine 
measures have had a considerable impact on resource availability of local self-government in the next quarters.

The Parliament adopted Laws No 533-IX [29] and No 540-IX [27], which:

- exempt, for the period from 1 March to 31 September, from imposing by a land charge, an immovable property tax as well as provides a nonapplication of penalty sanctions for tax legislation violations;

- set a moratorium on conducting documentary and actual inspections;

- increase a maximum income amount allowing to pay a single tax (group I - from UAH $300 \mathrm{~K}$ to UAH $1 \mathrm{M}$; group II - from UAH $1.5 \mathrm{M}$ to UAH $5 \mathrm{M}$; group III - from UAH $5 \mathrm{M}$ to UAH $7 \mathrm{M}$ );

- extend a list of expenses, which may be included to obtain a tax allowance;

- postpone the submission of the annual asset and income declaration for 2019 (extend the declaration deadlines from 1 May to 1 July 2020).

Changes in the budgetary and tax legislation adopted during 2020 concerning prevention of the occurrence and spread of the COVID-19 acute respiratory disease as well as an impact of the implementation of quarantine measures have reflected, to a great extent, in the resource provision of local self-government.

For January - June 2020, local budgets (exclusive of inter-budgetary transfers) received UAH $139.8 \mathrm{~B}$ that is by UAH $660.5 \mathrm{M}$, or $-0.5 \%$ less than for the same period of 2019 (Figure 9).

Among the main budget-forming revenues of local budgets, the receipt situation is as follows: UAH $81.0 \mathrm{~B}$ of PIT were received that is by UAH $3.8 \mathrm{~B}$, or $50 \%$ more than in 2019; UAH 5.3 B of CPT were received that is by UAH $13.3 \mathrm{M}$, or $0.3 \%$ less than in 2019 ; UAH $3.6 \mathrm{~B}$ of RSU were received that is by UAH $735.6 \mathrm{M}$, or $27.8 \%$ less than in 2019; UAH $3.3 \mathrm{~B}$ of excise duty on tobacco and alcohol were received that is by UAH $440.5 \mathrm{M}$, $15.3 \%$ more than in 2019 (Figure 10).

Among local taxes and levies, the dynamics is as follows: land charge receipts were UAH 13.3 B, a receipts decrease versus January - September of the previous year is $\mathrm{UAH} 2.3 \mathrm{~B}$, or $-14.5 \%$; immovable property tax receipts for January - September 2020 is UAH $2.3 \mathrm{~B}$ that is by UAH $162.1 \mathrm{M}$, or $7.7 \%$ more than in 2019; single tax receipts were $\mathrm{UAH} 17.7 \mathrm{~B}$ that is by UAH $1.6 \mathrm{~B}$, or $9.6 \%$ more than in 2019 (Figure 11). 


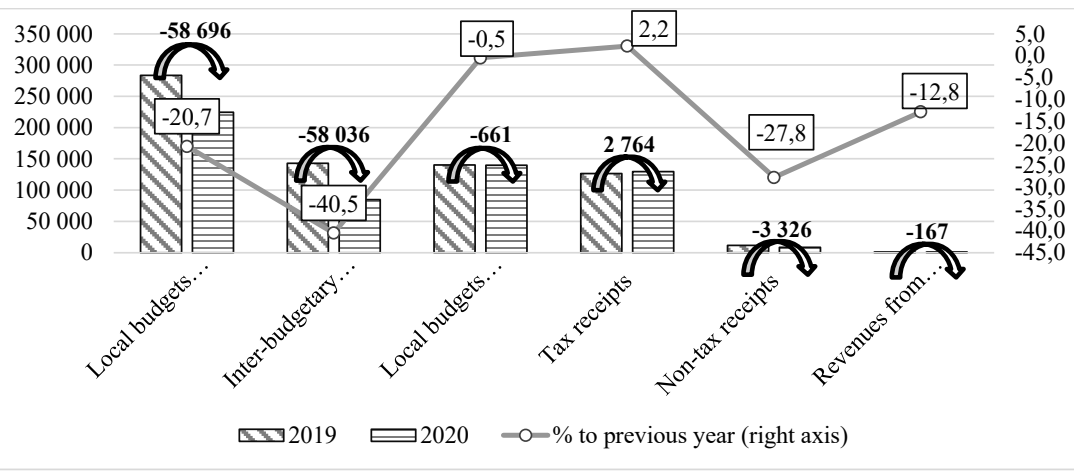

Figure 9. Local Budgets Revenues Amounts Comparison

for January - June 2020 and the same period of the previous year

Source: Calculated and compiled on the basis of data of the State Treasury Service of Ukraine [12]

Implementing quarantine measures in connections with COVID-19, in general, have adversely affected the local budgets receipts, in particular, a rent charge and a charge for use of other natural resources

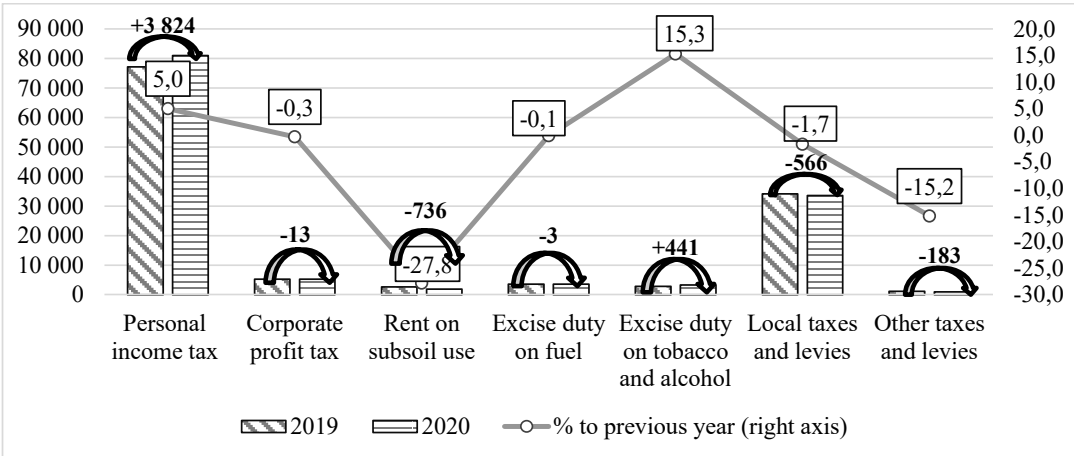

Figure 10. Basic Local Budgets Revenues Sources Amounts Comparison for January - June 2020 and the Same Period of the Previous Year

Source: Calculated and compiled on the basis of data of the State Treasury Service of Ukraine [12] 


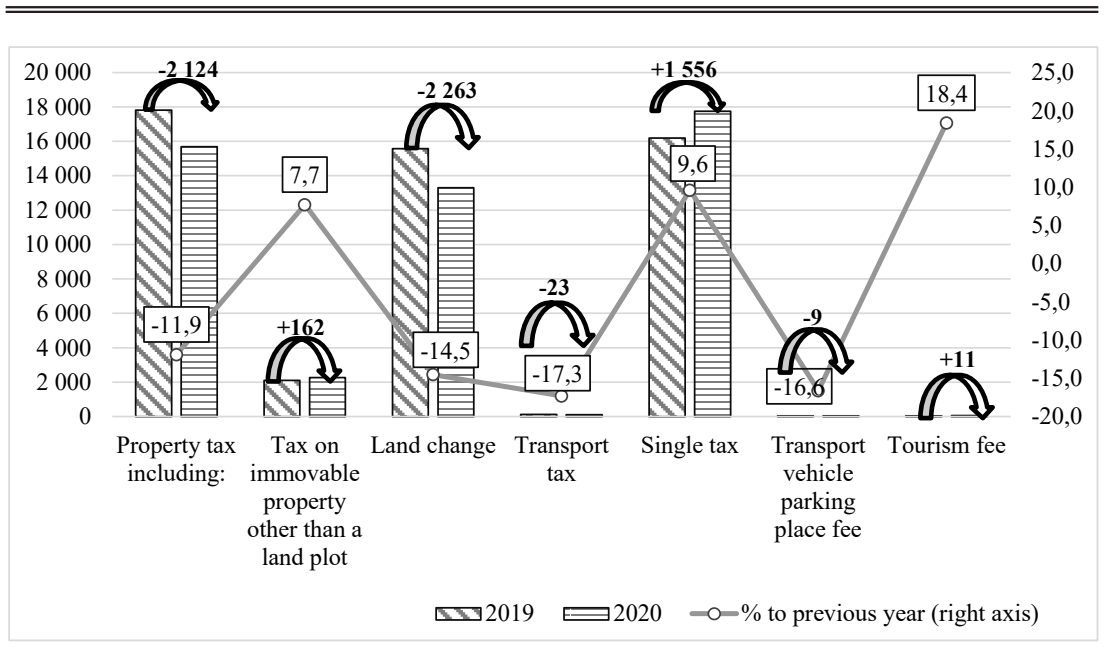

\section{Figure 11. Local Budgets Local Taxes and Levies Receipts Comparison for January - September 2020 and the Same Period of the Previous Year}

Source: Calculated and compiled on the basis of data of the State Treasury Service of Ukraine [12]

for January - September 2020 were by $27.8 \%$ less than in 2019: UAH 2,649.7 $\mathrm{M}$ in 2019 versus UAH 1,914.1 $\mathrm{M}$ in 2020; excise duty receipts reduced by UAH 2.8 M, from UAH 3,560.2 M to UAH 3,577.4 M. Positive dynamics is observed for personal income tax receipts only (in 2020, a gain was $5.0 \%$, or UAH $3,823.6 \mathrm{M}$, positive dynamics is caused by an annul natural growth in wages and recovery of business activity) and excise duty on tobacco and alcohol (in 2020, a gain was $15.3 \%$, or UAH $400 \mathrm{M}$ ).

For the purpose of formation of the Fund of Fighting the COVID-19 Acute Respiratory Disease and Its Consequences, on 13 April 2020, by amendments introduced to the State Budget of Ukraine for 2020 (Law No 553-IX [28]), a number of state programs were cut. As a consequence, local budgets suffered losses in the amount of UAH 9.65 B, in particular, caused by reducing in the amount of the funds of the State Fund of Regional Development by UAH 2.6 B, subventions to hold elections of deputies of local councils and village, settlement and city chairmen by UAH 1.15 B, subventions to support the development of ATCs by UAH 2.1 B, subventions 
to improve social protection of specific categories of pedagogical workers of general secondary education establishments by UAH 1.55 B, subventions to implement the Able School for Best Results program by UAH 1 B etc.

A necessity to form a fund has caused cutting back a number of budget programs including those relating to ATCs. The latter have actively joint counteracting the spread of the COVID-19 acute respiratory disease - in addition to introducing and implementing quarantine measures at the territorial communities level, local self-government has channeled funds for increasing wages for medical and other workers directly involved in works on liquidating the COVID-19 disease, purchasing drugs, masks, tests, equipment, organizing transportation of medics to work, delivery of products for elderly people and socially vulnerable families [5].

Adopted Law No 553-IX [28] provides that, temporarily, for the period of the effect of the quarantine or restrictive measures associated with the spread of the coronavirus disease, the enterprises of centralized water supply and water disposal regardless of the form of ownership as well as heat energy producers regardless of the form of ownership shall be released from charging fines and penalty sanctions by electricity and natural gas suppliers.

Law No 553-IX also provides further recovery of state budget expenditures (including transfers to local budgets) and granting credits from the state budget under budget programs cut in connection with the establishment of the Fund for Fighting the COVID-19 Acute Respiratory Disease and Its Consequences. In addition, the Government promised, in response to a specific appeal of the parliamentary Budget Committee, to channel UAH 1.5 B to support the development of ATCs. The parliamentary committee sent the Government a relevant appeal.

Analyzing receipts, by months, of the second quarter and comparison of indicators of 2019 and 2020 gives evidence of considerable losses of local budgets:

- revenues of local budgets inclusive of transfers in April - May 2020 are less by $30 \%$ than in 2019 ;

- receipts of inter-budgetary transfers reduced twofold;

- in April 2020, own revenues of local budgets were UAH 20,259.0 M that is by $20 \%$ less than in April 2019, and, in May 2020, own revenues of local budgets amounted to UAH $24,096.6 \mathrm{M}$ that is by $7.5 \%$ less than in 2019 ; 
- in April 2020, tax receipts were UAH 18,997.1 M that is by $17.9 \%$ less than in 2019, and, in May 2020, they were UAH 22,771.7 M that is by $4.5 \%$ less than in the previous year;

- in April - May 2020, non-tax receipts were two times less than the 2019 indicators (Figure 12).

From 22 May, Ukraine has moved to the adaptive quarantine - this is a period, during which most restrictions are gradually removed. Business activities are gradually resumed: economic entities of wholesale and retail sale, repair of motor vehicles, post and courier activities, insurance activities, art, sports, entertainment and recreation are allowed to work. From 1 June, Ukraine has moved to the next stage of quarantine easing: public catering facilities are allowed to receive visitors in the premises subject to compliance with anti-epidemic measures, the operation of interoblast passenger transportations is resumed etc.

In June 2020, local budgets revenues (inclusive of transfers) have started to grow as compared to April, May 2020, however, in comparison to indicators of June 2019 they are still less by $-12.9 \%$ (UAH $-6,392.5 \mathrm{M}$ ).

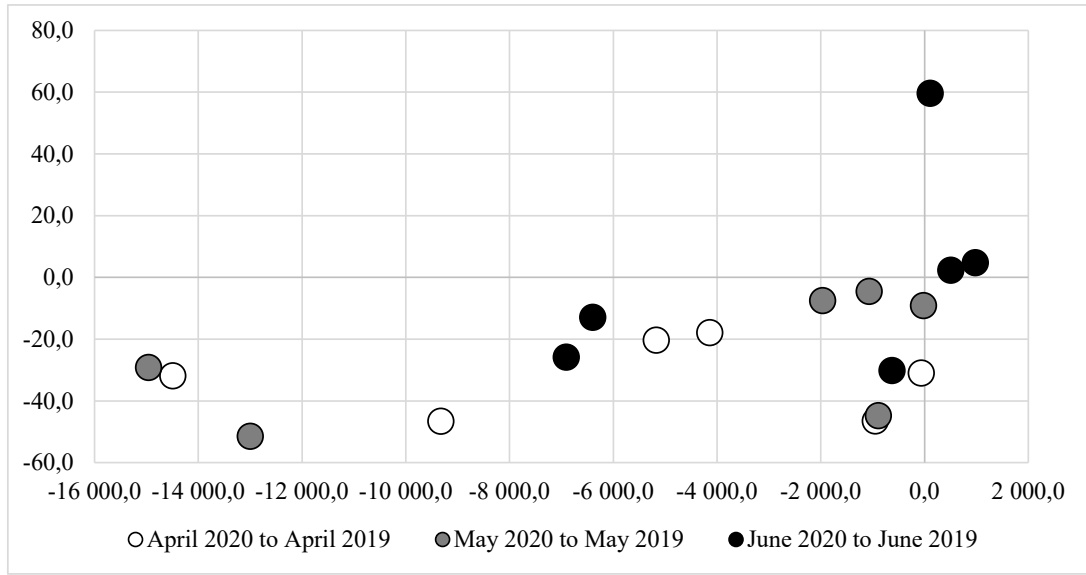

Figure 12. Local Budgets Revenues Amounts Comparison in the Second Quarter of $\mathbf{2 0 2 0}$ and the Same Period of the Previous Year

Source: Calculated and compiled on the basis of data of the State Treasury Service of Ukraine [12] 
In June 2020, own revenues of local budgets amounted to UAH $510.8 \mathrm{M}$ that is by $+2.3 \%$ more than the same indicator of 2019 .

Meanwhile, shortfalls could have been even larger, however, loss of personal income tax of all local budgets was prevented. Law No 591-IX (draft law No 3329-d in a version to a second reading) adopted on 13 May 2020 contains a norm allowing, through a mechanism of the monetary compensation from the state budget, to comprehensively solve a matter of support for medical workers and prevent losses of PIT of local budgets. In addition, Law No 591-IX granted ATCs the right to expeditiously make decisions on introducing amendments to adopted resolutions on establishing local taxes and levies as to lowering rates of land charge and/or tax on immovable property other than a land plot, concerning non-residential real estate owned by individuals or legal entities.

Analyzing indicators of basic revenues sources of local budgets, by months of the second quarter, gives evidence of the sensitive adverse impact of introduction of quarantine measures on budgets indicators:

in April 2020, personal income tax receipts were by UAH $498.3 \mathrm{M}$ $(-3.7 \%)$ less than in 2019; in May 2020, receipts were by UAH $681.0 \mathrm{M}$ $(-5.2 \%)$ less than in May 2019;

in April 2020, receipts of excise duty on fuel amounted to UAH $638.6 \mathrm{M}$ that is by UAH 1,630.0 M (-71.9\%) less than in April 2019; in May 2020, receipts of excise duty amounted to UAH $682.5 \mathrm{M}$ that is by UAH $37.2 \mathrm{M}$ $(-5.2 \%)$ less than in May 2019;

in April 2020, receipts of local taxes and levies amounted to UAH 4,457.8 $\mathrm{M}$ that is by UAH 1,971.9 M (-30.7\%) less than in April 2019; in May 2020, receipts of local tax and levies amounted to UAH 5,932.1 M that is by UAH 339.2 M (-5.4\%), less than in May 2019 (Figure 13).

In June 2020, local budgets revenues (inclusive of transfers), as compared to April and May 2020, started to grow, however, versus indicators of June 2019, they are still lower by $12.9 \%$ (UAH 6,392.5 M). In June 2020, own revenues of local budgets amounted to UAH $510.8 \mathrm{M}$ that is by $+2.3 \%$ more than the same indicator of 2019 p. Due to recovery of business activities in June 2020, positive dynamics, as compared to June 2019, was shown by indicators of receipts of personal income tax $(+1.5 \%$, or $+\mathrm{UAH} 218.3 \mathrm{M})$, excise on fuel $(+30.3 \%$, or $+\mathrm{UAH}$ 173.6 M), excise on tobacco and alcohol $(+17.1 \%$, or $+\mathrm{UAH} 84.5 \mathrm{M})$, local taxes and levies $(+20.5 \%$, or + UAH $817.3 \mathrm{M})$. 


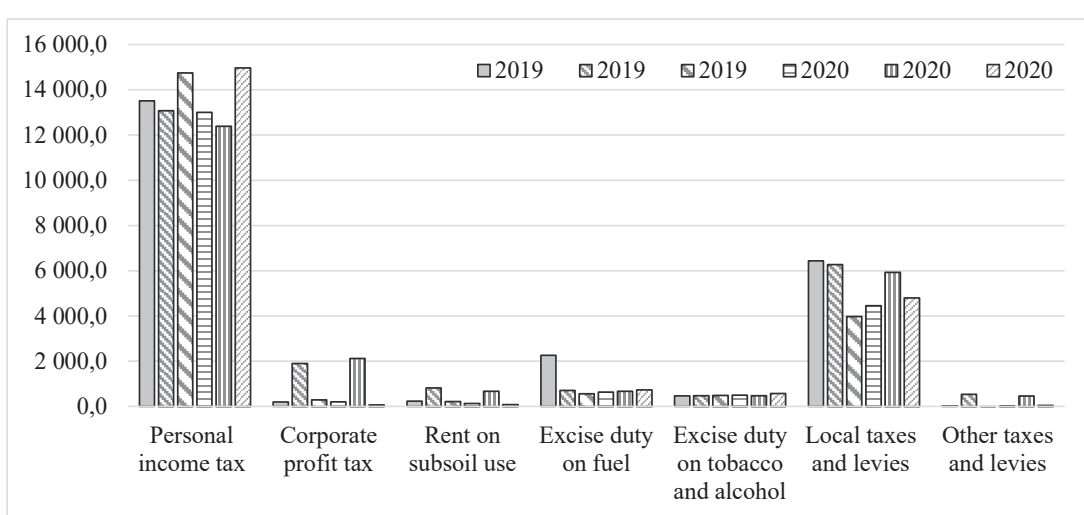

\section{Figure 13. Basic Local Budgets Revenues Sources Receipts in the Second Quarter 2020 and the Same Period of the Previous Year, UAH M}

Source: Calculated and compiled on the basis of data of the State Treasury Service of Ukraine [12]

The amount of receipts of the main budget-forming source of local budgets - personal income tax - is, for January - September 2020, UAH 81,027.7 M. As compared to the same period of 2019, a gain in receipts is $5.0 \%$ (+UAH 3,823.6 M) (Figure 14).

Among the revenues, which showed positive dynamics, there are receipts of corporate profit tax, excise duty on tobacco and alcohol.

In June 2020, due to recovery of business activities, positive dynamics, as compared to June 2019, was shown by indicators of receipts of personal income tax $(+1.5 \%$, or $+\mathrm{UAH} 218.3 \mathrm{M})$, excise duty on fuel $(+30.3 \%$, or $+\mathrm{UAH} 173.6 \mathrm{M})$, excise duty on tobacco and alcohol $(+17.1 \%$, or +UAH $84.5 \mathrm{M})$, local taxes and levies (+20.5\%, or +UAH $817.3 \mathrm{M})$ as well as other taxes and levies $(+29.6 \%$, or $+\mathrm{UAH} 29.6 \mathrm{M})$. However, receipts of corporate profit tax and rent charge and rent on use of other natural resources have recovered to 2019 indicators.

Under the conditions of consideration of monthly indicators of receipts, the following situation is observed:

- in April 2020, receipts of property tax were by UAH 1,980.3 M (-57\%) less than in April 2019, and in May 2020, by UAH 698.4 M (-24.3\%) less than in May 2019; 


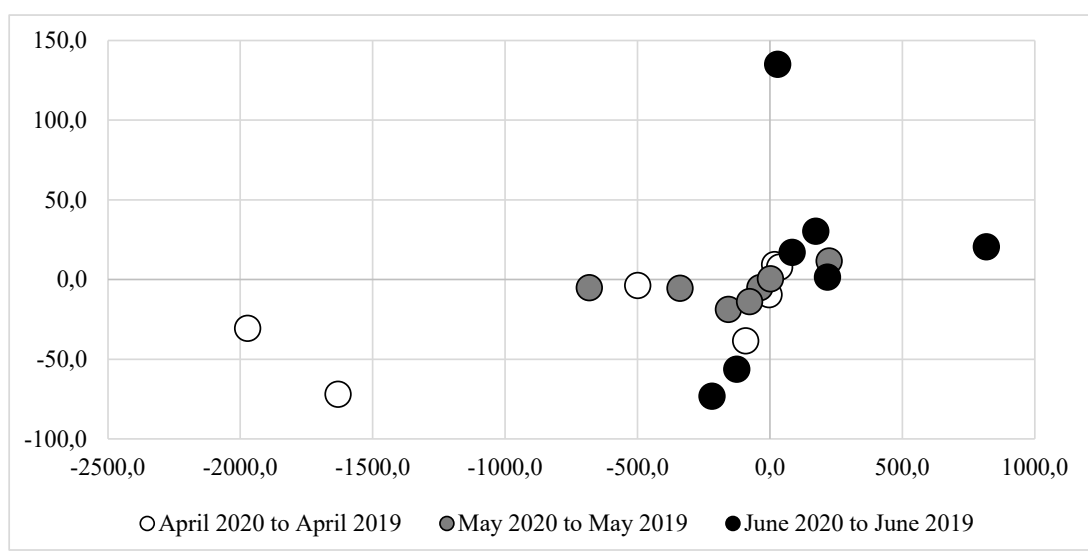

Figure 14. Basic Local Budgets Revenues Sources Amounts Comparison in the Second Quarter of 2019 in the Same Period of the Previous Year

Source: Calculated and compiled on the basis of data of the State Treasury Service of Ukraine [12]

- in April 2020, receipts of immovable property tax were by UAH 172.2 M (-20.9\%) less than in April 2019, and in May 2020, by UAH 698.4 M (-24.3\%) less than in May 2019;

- in April 2020, receipts of land charge amounted to UAH $820.9 \mathrm{M}$ that is by UAH 1,799.4 M (-68.7\%) less than in April 2019; in May 2020 , receipts of land charge were equal to UAH $1,994.8 \mathrm{M}$ that is by UAH 713.2 M (-26.3\%) less than in May 2019;

- in June 2020, receipts of immovable property tax amounted to UAH 329.7 M that is by UAH 87.9 M, or $36.4 \%$ more than in June 2019, of land charge-UAH 3,279.2 M that is by UAH 611.2 M, 22.9\% more (Figure 15-16).

Single tax receipts, despite implementing quarantine measures, and, as a consequence, suspending entrepreneurial activities in the respective period, shows positive dynamics, however, it is slight that is caused by objective conditions of economic management in the quarantine period. In April 2020, single tax receipts amounted to UAH 2,954.8 M that is by UAH 15.1 M (+0.5\%) more than in April 2019, and in May 2020, they were equal to UAH 3,728.9 $\mathrm{M}$ that is by $\mathrm{UAH} 359.8 \mathrm{M}(+10.7 \%)$ more than 


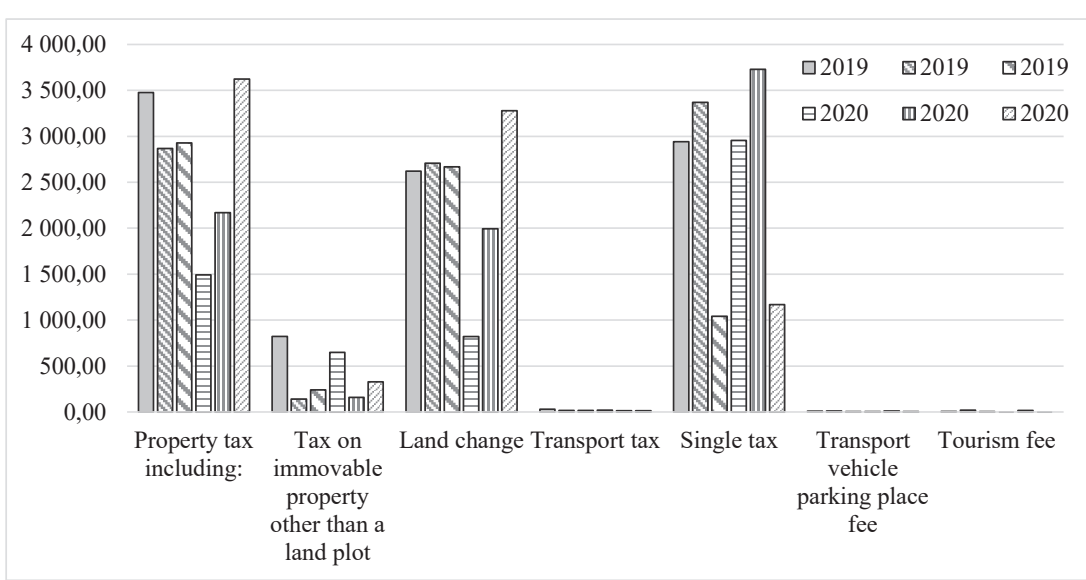

Figure 15. Local Budgets Local Taxes and Levies Receipts

Comparison in the Second Quarter of 2020 and the Same Period of the Previous Year, UAH M

Source: Calculated and compiled on the basis of data of the State Treasury Service of Ukraine [12]

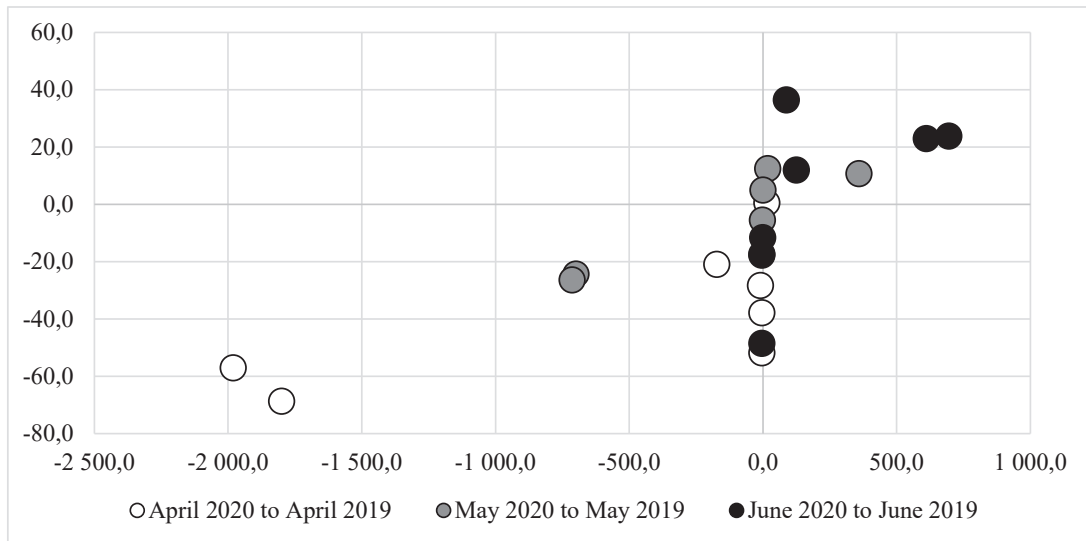

Figure 16. Local Budgets Local Taxes Receipts Comparison in the Second Quarter 2020 and the Same Period of the Previous Year Source: Calculated and compiled on the basis of data of the State Treasury Service of Ukraine [12] 
in April 2019; in June 2020, they amounted to UAH 1,169.3 M that is by UAH $125.4 \mathrm{M}$, or $12.0 \%$ more than a 2019 indicator.

Therefore, in the second quarter, positive dynamics is observed in receipts, into local budgets, of personal income tax (in 2020, a gain was equal to $5.0 \%$, or UAH $3,823.6 \mathrm{M}$, positive dynamics is caused by increasing in wages and recovery of business activities) and excise duty on tobacco and alcohol (in 2020, a gain was $15.3 \%$, or UAH $400 \mathrm{M}$ ).

In the third quarter, the parliament adopted a resolution to restore the amount of expenditures for local elections, which were reduced in the second quarter through the formation of the Fund of Fighting COVID-19. On 13 July 2020, the Verkhovna Rada of Ukraine adopted Law No 757-IX, which restored (increased by UAH $1.26 \mathrm{~B}$ ) the amount of expenditures to hold local elections. However, No 757-IX has not accounted for a need for additional expenditures, which will arise in connection with planned amendments to the electoral legislation in terms of the extension of the proportional electoral system to the most communities as well as expenditures for the implementation of measures aimed at preventing the spread of COVID-19 during organization and holding of local elections.

For January - September 2020, local budgets received (exclusive of inter-budgetary transfers) UAH $219.8 \mathrm{M}$ that is by UAH $3 \mathrm{~B}$, or $1.4 \%$ more than for the same period of 2019 (Figure 17).

During January - September, the Government remitted inter-budgetary transfers to local budgets in the amount of UAH $116.7 \mathrm{M}$ : a base grant was remitted in the amount of UAH 9.9 B (100\% according to a breakdown of appropriations); an educational subvention was remitted in the amount of UAH 59.6 B (99.9\% according to a breakdown).

As to other transfers, on 8 July 2020, the Government of Ukraine approved the allocation of UAH $1.68 \mathrm{~B}$ of subventions to carry out measures for socioeconomic development of specific territories, having adopted a respective order. It is provided to channel subvention funds for the implementation of nearly 1,200 projects, in particular, for capital repair and reconstruction of socioeconomic infrastructure facilities (hospitals, schools, sports facilities, roads), for repair of street lighting, reconstruction of water supply networks, procurement of medical equipment for healthcare institutions. Of the total amount of subventions, UAH 17.97 M remain not allocated. It is provided that, in 2020, the 


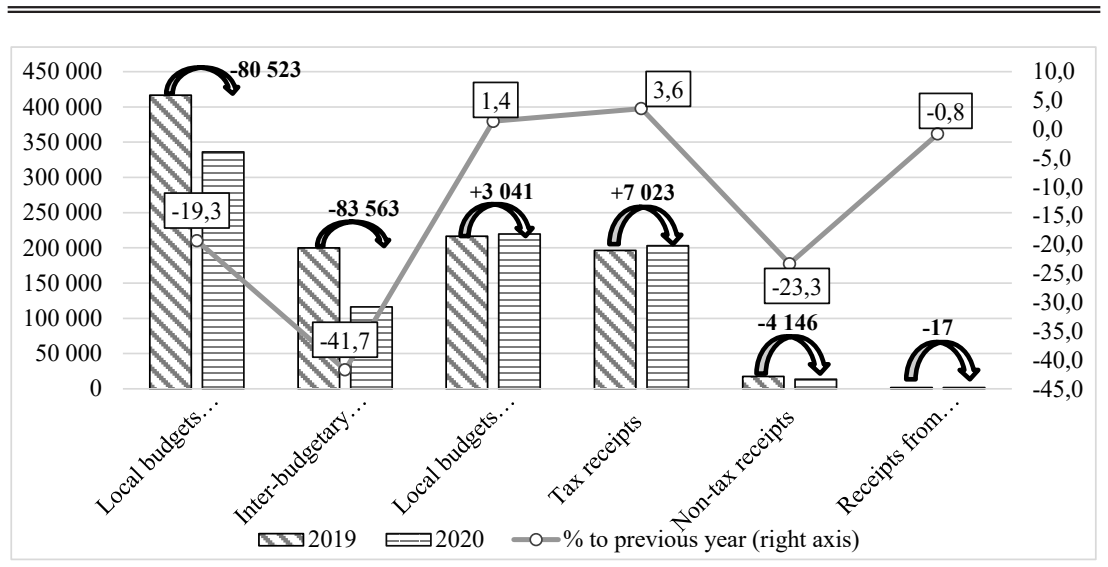

\section{Figure 17. Local Budgets Revenues Amounts Comparison for January - September 2020 and the Same Period of the Previous Year \\ Source: Calculated and compiled on the basis of data of the State Treasury Service of Ukraine [12]}

subvention will be channeled, first of all, for carrying out measures aimed at fighting COVID-19.

Among the basic budget-forming revenues of local budget, the situation with receipts is as follows [24]: receipts of PIT amounted to UAH 125.9 M that is by UAH $6.7 \mathrm{~B}$, or by $5.6 \%$ more than in 2019; land charge receipts amounted to UAH 23.2 B, a decrease in receipts versus January - September of the previous year is UAH $1.8 \mathrm{~B}$, or $-7.2 \%$; For January - September 2020, immovable property tax receipts amounted to UAH $4.2 \mathrm{~B}$ that is by UAH $0.5 \mathrm{~B}$, or $14.7 \%$ more than in 2019 ; single tax receipts were UAH 26.5 B that is by UAH $1.8 \mathrm{~B}$, or $7.3 \%$ more than in 2019 .

On 19 August, the Government allocated the assignment of a portion of excise duty to budgets of local self-government in the second half of 2020 . For January - September, receipts into budgets of local self-government amounted to UAH $5.9 \mathrm{~B}$ that is by $0.3 \mathrm{~B}$, or by $6.0 \%$ more than in 2019 .

Analyzing receipts, by months of the third quarter and comparing respective indicators of 2019 and 2020, gives evidence of further considerable losses of local budgets (Figure 18).

On 2 September 2020, the Parliament adopted, in a first reading, the draft Law "On Introduction of Amendments to the Tax Code of Ukraine 


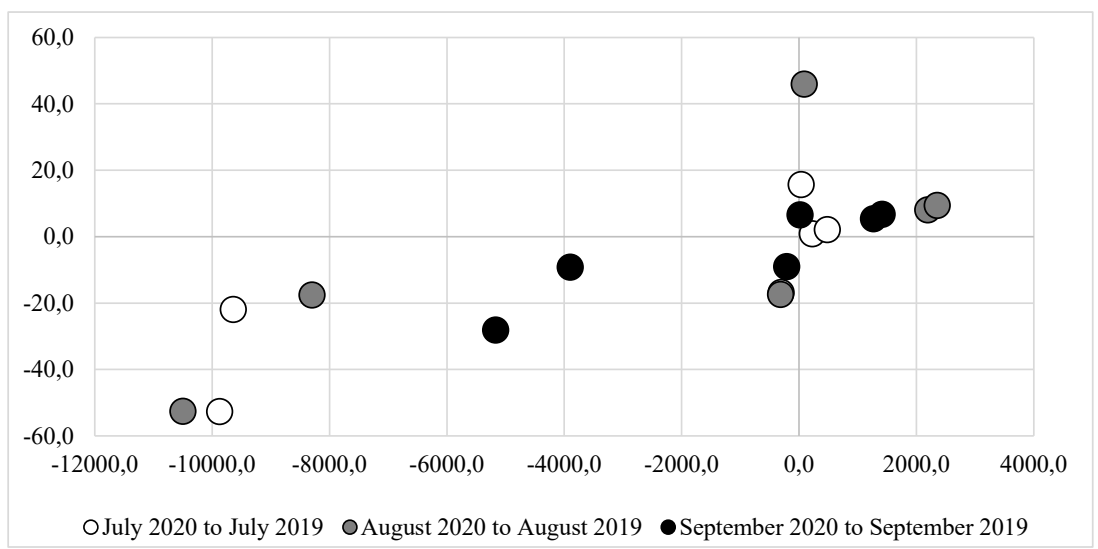

Figure 18. Local Budgets Revenues Amounts Comparison in the Third Quarter of 2020 and the Same Period of the Previous Year

Source: Calculated and compiled on the basis of data of the State Treasury Service of Ukraine [12]

and Some Legislative Acts of Ukraine on Stimulation of Development of Electric Transport in Ukraine" (reg. No 3476 of 14.05.2020). Amendments provided by a draft Law will adversely affect the revenue side of local budgets as they will lead to receipts losses of local budgets through the requirement to return PIT according to the results of annual declaration of tax sums paid for the accounting period to payers, which will use the right for a tax allowance. According to calculation of Minfin [15], the expected sum of losses of personal income tax will amount, at least, to UAH 580.0 M. So, the parliamentarians took a step to solve the matter of stimulation of development of specific industries of the economy for the account of local budgets (Figure 19-20).

In addition, during the third quarter, legislative initiatives appeared that have an adverse impact on financial capacity of budgets of local selfgovernment, will significantly reduce their amounts and lead to unbalancing budgets of cities, villages and settlements, and to critical underfinancing already planned measures in education, healthcare, social security and other, inter alia, measures aimed at preventing the occurrence and spread of the coronavirus infection, in particular: 


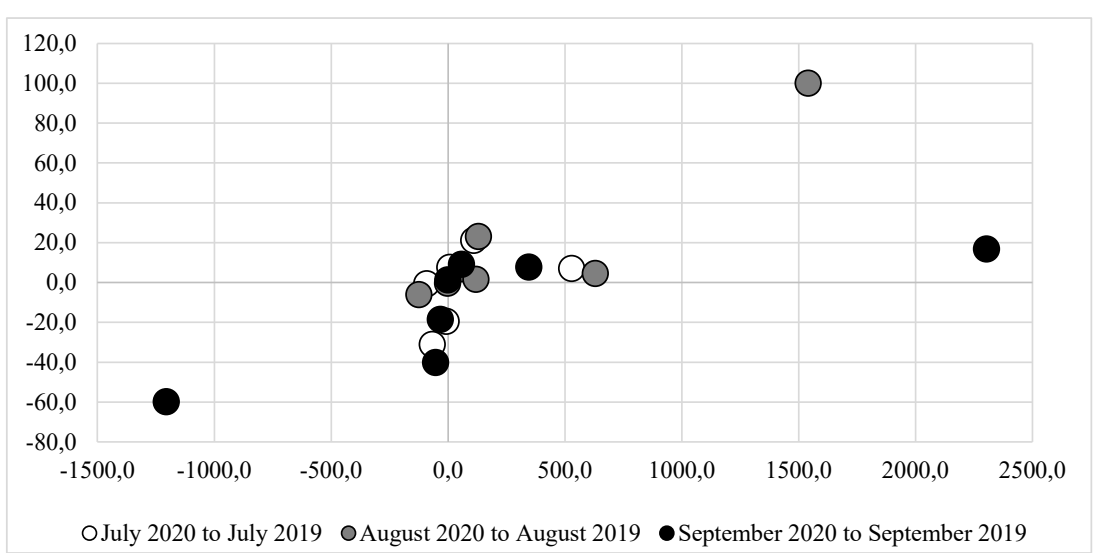

\section{Figure 19. Basic Local Budgets Revenues Receipts}

Amounts Comparison in the Third Quarter of 2020 and the Same Period of the Previous Year

Source: Calculated and compiled on the basis of data of the State Treasury Service of Ukraine [12]

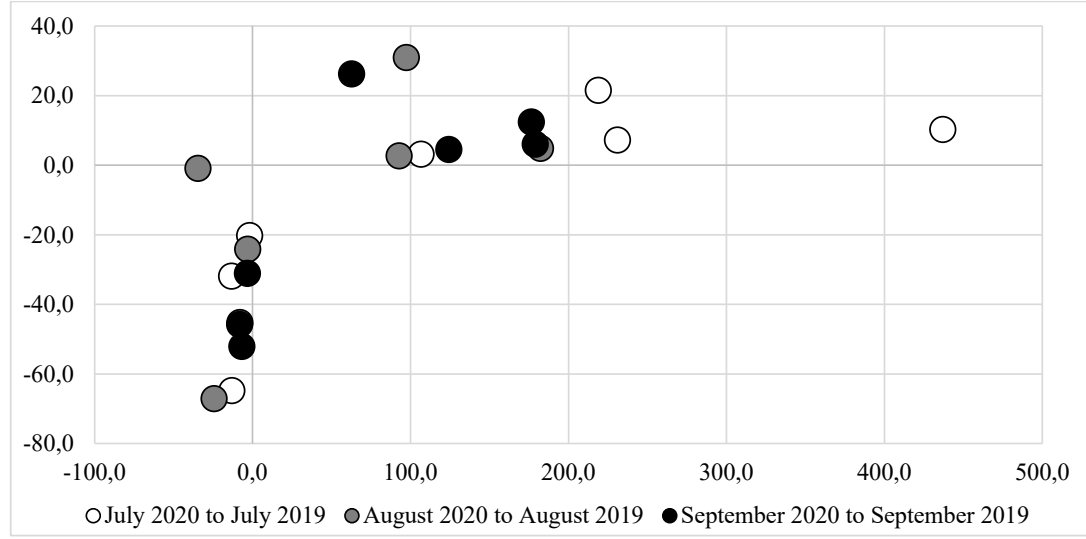

Figure 20. Local Budgets Local taxes and Levies Receipts Comparison in the Third Quarter of 2020 and the Same Period of the Previous Year

Source: Calculated and compiled on the basis of data of the State Treasury Service of Ukraine [12] 
1) at the parliament, a draft Law "On Introduction of Amendments to the Tax Code of Ukraine and Some Other Laws of Ukraine on Measures for Stimulation of Economy of Ukraine" No 3848 of 15.07.2020 is registered [38], which will adversely impact on financial capacity of local budgets. A draft Law proposes to grant reliefs for land charge and immovable property tax during the quarantine and for 3 months after the date of its completion. According to our estimates, losses on these taxes because of proposed legislative initiatives will amount to UAH 3.2 B per month;

2) Minenerho developed a draft Law of Ukraine "On Introduction of Amendments to Article 283 of the Tax Code of Ukraine" [6], which proposes to exempt from imposing land tax on the lands, which are contaminated by radioactive substances, and on uranium production waste storage sites, buildings and structures of the former uranium production PA "Prydniprovskyi Chemical Plant" including those, on which engineering-and-technical complexes for protection of facilities and area of this production amalgamation are located. According to our estimates, annual land tax losses from proposed legislative initiatives will be, at least, UAH 7.0 M.

In the third quarter, the following draft laws aimed at improving the state of local finances are registered at the parliament:

- a draft Law "On Introduction of Amendments to the Budget Code of Ukraine Concerning Application of Formula Allocation of Subventions for Roads" of 22.07.2020, No 3919 [36];

- a draft Law "On Introduction of Amendments to the Law of Ukraine "On Sources of Financing of Road Facilities of Ukraine" Concerning Application of Formula Allocation of Subventions for Roads" of 22.07.2020, No 3921;

- a draft Law "On Introduction of Amendments to the Tax Code of Ukraine (Concerning Providing Compliance of Tax Legislation with Principles of Financial Sufficiency and Equality of All Payers under the Law)" No 3923 of 22.07.2020.

However, the bodies of local self-government undertook a number of unplanned additional expenditures in the third quarter, So, local selfgovernment faced the challenges of the need to liquidate the consequences of flooding, recovery of infrastructure and provision of assistance to citizens, who suffered from a natural disaster. Bad weather in Ukraine due 
to a fallout of intense long precipitation in June 2020 caused destructive floods, landslides. Due to the bad weather, roads are ruined, individual areas are practically isolated, dams burst and bridges are damaged, agricultural lands, private houses and property are flooded, unfortunately, a disaster also claimed human lives.

On 3 July, the Verkhovna Rada of Ukraine adopted Law No 743-IX "On Introduction of Amendments to the Law of Ukraine "On State Budget of Ukraine for 2020" (draft No 3776) [37], which increased by UAH 2 B, the amount of the reserve fund of the state budget to ensure the financing of measures for neutralizing the adverse consequences of the flood in western oblasts of Ukraine that happened in June 2020, However, the need is at least UAH 10 B.

Just as in the second quarter, the bodies of local self-government continued to undertake the expenditures for procurement of goods needed for carrying out measures for fighting the coronavirus. According to date of the Derzhkaznacheistvo, as of 1 October 2020, for procurement of goods and services for the prevention of the spread of CIVID-19, for the account of budgets of all levels, payments to the amount of UAH $6.75 \mathrm{~B}$ are made: UAH 3.39 B from the state budget and UAH 3.36 B from local budgets.

Of UAH 3.36 B of the expenditures of local budgets, it is spent on fighting COVID-19:

- UAH 1.273 B on procurement of medications, medical products and expandable materials;

- UAH 1.2863 B on procurement of medical equipment as fixed assets;

- UAH 457.5 M on procurement of medical masks, antiseptic disinfection means, express tests, low-value medical equipment;

- UAH 303.0 M on services for the provision of irregular passenger transportations and services for sanitary-and-hygienic premises treatment;

- UAH 13.4 M on services for the provision of catering to patients ill with COVID-19, and to medical workers.

Results of the survey conducted by the European Business Association show that one third of small entrepreneurs lost over $50 \%$ of revenues by the effect of the quarantine. Enterprises also inform of the considerable growth in receivables. Further $44 \%$ suffered up to $50 \%$ of revenue losses and $7 \%$ of enterprises consider an option of closing. And only 14\% have experienced no changes in their work or even had an income growth. Most companies, 
namely $48 \%$, managed to keep personnel wages unchanged while $29 \%$ were forced to cut a rate of labor payment and further $19 \%$ - to place workers on unpaid leave. $59 \%$ of enterprises managed to keep the company personnel unchanged. Further 33\% of companies dealt with cuts, and over $6 \%$ even now look for new workers [41].

A special role in supporting entrepreneurs under the conditions of overcoming the consequences of COVID-19 is cast for the bodies of local self-government having a number of financial tools at their disposal. Actions of local self-government were aimed, first of all, at slowing down an economic drop, preserving enterprises from bankruptcy, keeping jobs and recovery of the economy after the end of the quarantine. For this purpose, the bodies of local self-government took the decision on exempting entrepreneurs from a number of taxes and other mandatory payments, for example, a single tax for entrepreneurs of groups I and II, a land charge and a tax on items of non-residential real estate, a charge for use of immovable communal property, under contracts for establishment of land servitude, rent payment for the quarantine period for a trading place in the market etc. individual bodies of local self-government developed complex local programs of financial support for entrepreneurs under the condition of fighting COVID-19.

It is worth noting that the bodies of local self-government carried out support under the conditions of additional financial pressure on the need for fighting COVID-19 (on procurement of goods, works and services, additional extra payments to wages of medical and other workers who are directly involved in works on the liquidation of the coronavirus disease), loss of considerable amount of receipts of budgets. And a weighty part of such losses is caused by decisions taken by the central power without a proper dialogue with the local power on taking such decisions.

A 2020 practice proved that the main tasks of the budgetary policy on local finances, which will help slow down an economic decline, preserve enterprises from bankruptcy, keep jobs, promote to fill budgets, accelerate recovery of the economy after the end of the quarantine, increase in revenues of employers and employees, provide timely payment of wages, are: strengthening a revenue base of budgets of local self-government by keeping stable sources of filling budgets (in particular, excise duties on fuel) and deepening diversification of such sources, undertaking the expenditures 
aimed at improving socioeconomic infrastructure of communities (including that for the account of funds of the State Fund for Regional Development).

\section{Corona Test for Rural Economy: A Matter of Theory, Methodology and Empirics}

There is no clear definition of "rural economy" in the Ukrainian legislation despite a large number of various legal documents available, which use this term. For the first time, an attempt to give an official definition for the term "rural economy" is made in the draft Law of Ukraine "On Fundamental Principles of State Agrarian Policy and State Rural Development Policy" [39], which offers a definition of the said category subject to a need to implements a concept of sustainable development, namely: "a process where improving quality of life and economic welfare of population living in the rural area is interconnected and interdependent" [39]. This draft law also provides that sustainable rural development includes consistency of social, economic and environmental measurements.

The term "rural economy" is actively used in the Concept of Development of Rural Areas [35] (Concept), along with categories "rural development" and "development of rural areas". It is provided that implementing the Concept will enable to shift a focus of the state agrarian policy from supporting the agrarian sector of the economy to supporting rural development - improving quality of life and economic welfare of rural population. According to the provisions of the Concept, rural development consists in creating conditions to ensure complex development of rural areas in the interests of society that provides rational formation of competitive multi-branch and multi-structure agriculture, diversified rural economy, favorable living environment based on increasing in human and social capital, and developing government and business partnership The above will enable to reform a rural area development management system, activate initiativity and responsibility of territorial communities of villages and settlements, expand a sphere of labor application, increase revenues of rural population, and availability of basic services, normalize a demographic situation in most rural areas.

A current regional policy conducted against the background of complex large-scale reforms, first of all, under the conditions of expansion of decentralization processes, provides creating a system of multi-level government of development of areas in the country. It is possible only 
subject to systematic coordination of actions of the bodies of executive power, the bodies of local-self-government at all levels, representatives of business and civil society. Both horizontal coordination of actions of the bodies of state power, which have an impact on regional development and implementation of multi-level vertical management, which must promote synchronization of actions of the central and local bodies of executive power, become determinant [34].

Rural development matters have also been reflected in the State Strategy of Regional Development [33]. Considering that most newly-established amalgamated territorial communities are rural (1058 are rural and 380 are urban [21]), so, it is obvious that "the rural development policy at the national level requires involving, for its implementation, all bodies of state executive power, for which a rural area falls within their sphere of responsibility, and the bodies of local self-government" [33].

Ukraine is an agrarian state and agriculture remains a flagman of the economy and a key component of Ukrainian export - the branch forms nearly $12 \%$ of gross value-added, in which over 3 mill. people are employed, and which provides $44 \%$ of total export of the state [8].

According to data of the State Statistics Service of Ukraine [8], gross cereal yield in Ukraine increased by 12.32 mill. tons in 2015. A wheat harvesting area has not changed in 2015-2019 and was 6.8 mill. ha, however, sunflower and maize crop areas increased by nearly $20 \%$ reaching 11 mill. ha in 2019. At the same time, in 2018, a rapid growth was observed in maize yield up to $78.4 \mathrm{dt} / \mathrm{ha}$, more than by one third as compared to 2015. After the beginning of the quarantine, strict restrictions for cereal export have been introduced in Ukraine, however, considering that internal cereal consumption is $29 \%$ only, such decision is unprofitable not only for representatives of the branch but also for the state budget as food export annually brings nearly $40 \%$ of all currency receipts into the country (in 2019, the budget received nearly USD 9.6 B from cereal export [14]). In 2020 , because of unfavorable weather conditions, moisture deficiency in the wintertime and quarantine restriction consequences 62.2 mill. tons of wheat, barley and rape were gathered that is by $2 \%$ less than pessimistic expectations of the Ministry of Economic Development, Trade and Agriculture of Ukraine in the "Ukraine in 2020-2021: Aftermath of the Pandemic" Consensus Forecast (63.5 mill. tons were expected [48]). 
Under the conditions of declining in the rates of pay growth because of quarantine restrictions (in April, first from March 2016, real pay decreased by $0.5 \%$ as compared to the previous year because of low business activities and lower labor demand [11]) and livestock decline in animal husbandry, an extremely low annual rate of production growth is observed for the last ten years - at the $0.4 \%$ level (for comparison, in horticulture, a growth rate is nearly $5 \%$, in addition, the rates of receipts of capital investments into agriculture, forestry and fishery have decreased by $10 \%$, and receipts into animal husbandry - by $9.8 \%$ [8]). From 2015, cattle stock decreased by $19.7 \%$, that is by 3.4 mill. heads, the number of milk cows also declined by $20.2 \%$. Considerable damage was done to swine husbandry by the African swine fever. From 2015, the livestock decreased by $19 \%$, that is by 1.3 mill. heads. By milk production volumes, the branch reached a historic low in 2019.

Closure of almost 300 retail markets in Ukraine and partial restriction of public transport resulted in, on the one hand, severe losses of small agroproducers and sales growth in supermarket chains. In some cases, positive consequences were for organic farming as regular customers of retail markets provide themselves, at least temporarily, through Internet orders and postal sending of orders from eco-producers. On the other hand, the smallest producers cover own needs in the rural area and, thus, promote food security of Ukraine even in corona crisis times.

Global challenges of the last decade have caused structural changes in the economy of Ukraine and regions. In 2018, a share of gross value-added of types of economic activities of the overall volume of gross value-added of regions was: agrarian sector $-12 \%$, industry -24.4 , construction -2.7 , state management and defense, compulsory social insurance -7.1 , services $-53.8 \%$ $[14 ; 40 ; 52]$. A group of regions with predominantly agricultural specialization (more than in general in Ukraine) are Kirovohrad, Kherson, Khmelnytskyi, Vinnytsia, Chernihiv, Sumy and Ternopil Oblasts (Figure 21).

Leading rating positions are just partially a merit of local agrarians as basic factors providing grain gross are still natural factors - an area of a region itself, lands on its territory suitable for agriculture, and weather conditions. So, the least contribution to national agro-production is provided by Chernivtsy and Zakarpattia Oblasts while a leader is the Vinnytsia Oblast where the area of agricultural lands and arable lands is 1838.2 thous. ha, while in Chernivtsy and Zakarpattia Oblasts -442.6 and 387.7 thous. ha respectively. 


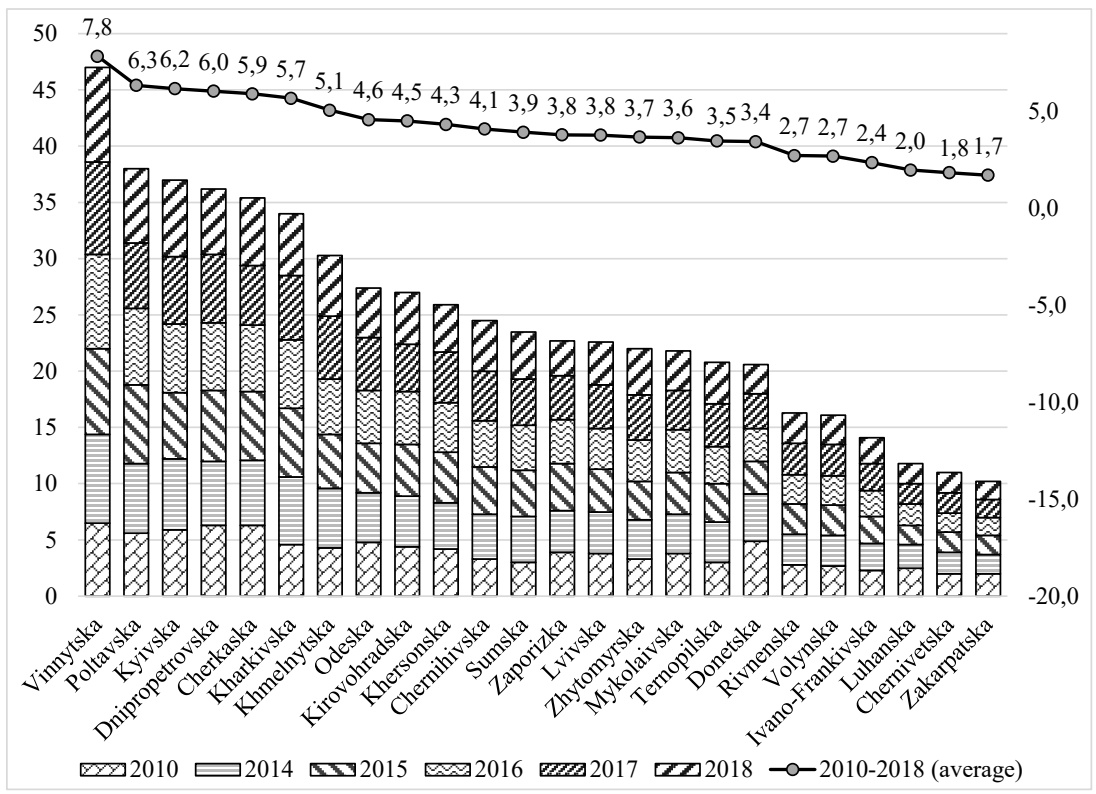

Figure 21. Dynamics of Regions Share of Overall Volume of Products of Agrarian Sector of Economy, \%

Source: Calculated and compiled based on data of the State Statistics Service of Ukraine [40]

By oblasts - basic animal husbandry product suppliers - the situation depends heavily on a corporate sector - location of large-scale commodity production. So, even one large agro-producer is sufficient to bring a region into the leaders: in the Vinnytsia Oblast (first place in the rating), basic capacities of the MHP agro-giant are located, the Zolotoniskyi Bekon Holding brought the Cherkasy Oblast to the second place and Danosha, a company with Danish investments dealing with swine husbandry, provided entering the TOP-10 by a totally non-agricultural Ivano-Frankivsk Oblast.

\section{Conclusions}

Studies conducted in the matters of development of the rural economy under the conditions of decentralization and corona crisis allowed to make theoretical generalizations and practical conclusions: 
first, a corona crisis, which occurred in 2020 and has already moved to 2021, has actually become a major trigger for defining how the world, in general, and Ukraine, in particular, will be developing in the next decade. There was a major break of a lifestyle that we had before. Ukrainian scientists (V. Heets, M. Zhurovskyi, P. Haidutskyi, V. Horbulin, I. Serhienko etc.), who are proponents of the view of cyclic of development of the economy prove that, at the end of the 1990 s, there was one crisis, in the "noughties" the other one, and the year 2020 was marked by a corona crisis, which will move by inertia at least three years (until 2023) according to two world scenarios suggested by the World Trade Organization. According to an optimistic scenario, a world trade decrease must have reached a level of $13 \%$, and in case of a pessimistic scenario - up to $32 \%$. However, even in April 2020, the Word Trade Organization projected that, according to a pessimistic scenario, we have to have a $24 \%$ growth in 2021 , and, according to an optimistic scenario even more $-27 \%$. In October, the World Trade Organization revised these scenarios and actually settled on the one, according to which the world trade, according to the results of 2020 , will reduce by $9.2 \%$. If we trace these forecasts through empirical results published by the State Statistics Service of Ukraine, then, in January - November 2020, Ukrainian export of agrarian products amounted to USD $20 \mathrm{~B}$ that is by $0.3 \%$, or USD $62.3 \mathrm{M}$ less as compared to the same period of the previous year, i.e., the agrarian sector and, respectively, the rural economy have not experienced a "shock" impact through a world coronavirus infection pandemic, however, it has provided predomination of agricultural products with a low-processing degree in the agrarian sector of the economy, having shaped, by that, the contours of the agrarian crises imbued with problems and threats in rural development;

second, a coronavirus pandemic has changed, in a matter of months, an established world order, having affected the absolute majority of the spheres of life activities, and the rural economy has not become an exception. So, for the first half of 2020 , food production reduced by nearly $19 \%$ (in comparison with the same period of the previous year) where the manufacturing of plant products reduced by $56.8 \%$, and of animal products by $2.2 \%$. By regions, the reduction took place in the following oblasts: Mykolaiv (by $8.4 \%$ ), Odesa (by $8.0 \%$ ), Zaporizhzhia (by $7.1 \%$ ), Kherson (by 6.7\%), Cherkasy (by 6.4\%), Poltava (by 5.7\%), Luhansk (by 5.6\%), 
Dnipropetrovsk (by 4.3\%), Kyiv (by 4.2\%), Rivne and Khmelnytskyi (by 3.8\%), Ternopil (by 3.6\%), Lviv (by 3.2\%), Volyn (by 1.9\%), Chernivtsy and Chernihiv (by $1.2 \%$ ), Sumy (by $0.9 \%$ ), Kharkiv (by $0.6 \%$ ). Having conducted extrapolation of anti-crisis measures of regulatory interference with the functioning of the rural economy, we obtained a clearly crystallized dual model, according to which at:

the national level, UAH 4 B are channeled for the respective measures, in particular, for "Partial Compensation for the Value of Agricultural Machinery and Equipment of Domestic Manufacture" (agrarians received compensation in the amount of nearly UAH $785 \mathrm{M}$ from UAH $1 \mathrm{~B}$ provided); "Financial Support for Measures in the Agro-Production Sector by Cheapening of Credits" (UAH 322.9 M and UAH 1.2 B, respectively); "Financial Support for Development of "Farm Households" (UAH 380 M are planned, however, has been started in August 2020 only); "State Support for Development of Animal Husbandry and Agricultural Products Processing" (UAH 1 B provided); "Financial Support for Development of Gardening, Viticulture and Hop Growing" (UAH 400 M provided); "Provision of Additional Financial Support to Farm Households through the Mechanism of Additional Payment in Favor of Insured Persons - Members/Head of Family Farm Household - of Single Contribution for Compulsory State Social Insurance" (UAH $20 \mathrm{M}$ are provided, the financing has started from September 2020 only) directions;

the local level, by forming respective, as a rule, three-year programs of development of the agrarian sector of the economy (and/or agriculture, rural areas), however, at the level (on the average, of UAH 1.5-2.0 M), which still does not allow not only to ensure an expected level of local value-added of agro-products but also shape the regulation architecture ideology from territorial communities (first of all, rural) of the institutional composition of the rural economy, bringing, to the forefront, their potential to support the said process, which closely correlates with own financial capacity;

third, a recession caused by COVID-19 and forced sequestration of the State Budget of Ukraine (Law of Ukraine "On Introduction of Amendments to the State Budget for 2020") has made a start of financial uncertainty and low predictability of formation of the revenue side of local budgets (according to preliminary calculations, probable losses amount to approximately UAH $10 \mathrm{~B}$ ) having posed not only a real threat 
to the implementation of the second stage of the decentralization reform in Ukraine (as of today, less than one fourth of tax-and-customs receipts goes directly to local budgets) but also having cancelled out a regulatory basis for sectoral modernization of the national and local economy, having essentially braked forming institutional capacity of territorial communities to regulate the rural economy, in particular, due to reduction in budgetary appropriations (by UAH 2.6 B to UAH $4.9 \mathrm{~B}$ ) for the functioning of the State Fund for Regional Development as well as has formed a steady trend towards delaying in establishing the Fund for Development of Rural Areas (provided by the Law of Ukraine "On Introduction of Amendments to Some Legislative Acts of Ukraine Concerning Conditions of Circulation of Agricultural Lands", which shall promote implementation of economic, social and infrastructure measures (projects) for improving living standards in rural areas under the conditions of free market circulation of agricultural lands, by accumulating funds needed to finance the following measures:

- financial support for recovery and development of the Internet, various types of rural infrastructure in a rural area;

- financial provision of implementation of measures for energy saving, development of education and medicine, rural tourism and hospitality services in the countryside;

- financial support for implementation of state programs for development of small and medium agricultural goods-producers;

fourth, for 2020, the general fund of local budgets received (exclusive of inter-budgetary transfers) UAH $290 \mathrm{~B}$. A gain in receipts into the general fund, versus 2019 (under comparable conditions and exclusive of areas uncontrolled by the Ukrainian power) was $5.4 \%$, or UAH $15.6 \mathrm{~B}$. A rate of growth of actual personal tax receipts for $2020 \mathrm{vs} 2019$ is $7.5 \%$, having reached a level of nearly UAH $178 \mathrm{~B}$ of land charge - UAH $31.5 \mathrm{~B}$ (decreased against the previous year by $4.1 \%$, and this is UAH $1.4 \mathrm{~B}$ ), tax on immovable property - UAH 5,7 $758.9 \mathrm{~B}$ (growth was nearly $18 \%$, or UAH 876,3 M), single tax - UAH 38 B (+7.8\%, or UAH 2.8 B). However, said quantitative indicators have not enabled to gain value-added from the functioning of the rural economy at the local level, having left a traditional level of regional dependence from the effectiveness of the performance of the agricultural production, which does not correlate, to a sufficient extent, with program values of stimulation of rural development (including 
agriculture and rural areas), cutting them, on a priority basis, against the background of the need to improve transport connection to timely deliver medical aid to the population, be in a position to test it for the presence of a coronavirus and do future vaccination.

\section{References:}

1. Iefymenko, T. (ed.) (2018) Aktualni problemy finansovoho upravlinnia: hlobalni tendentsii $i$ natsionalna praktyka [Current Problems of Financial Management: Global Trends and National Practice]. Kyiv: SESE "The Academy of Financial Management”. (in Ukrainian)

2. Cabinet of Ministers of Ukraine (2020) Audyt ekonomiky Ukrainy 2030 [Audit of the economy of Ukraine 2030]. Retrieved from: https://nes2030.org.ua/ docs/doc-audit.pdf (accessed 15 February 2021).

3. Government portal (2020, April 17) Biudzhetnyi protses u 2020 r. bude zdiisniuvatys z urakhuvanniam vplyvu pandemii COVID-19 [The budget process in 2020 will be carried out taking into account the impact of the COVID-19 pandemic]. Retrieved from: https://www.kmu.gov.ua/news/minfin-byudzhetnij-proces-u-2020-roci-bude-zdijsnyuvatis-z-urahuvannyam-vplivu-pandemiyi-covid-19 (accessed 15 February 2021).

4. Government portal (2020, July 1) Vykonannia derzhbiudzhetu za cherven 2020: $105 \%$ perevykonannia rozpysu podatkovoiu i $100 \%$ vykonannia planu mytnytseiu [Execution of the state budget for June 2020: 105\% overfulfillment of the tax schedule and $100 \%$ fulfillment of the plan by customs]. Retrieved from: https://www.kmu.gov.ua/news/vikonannya-derzhbyudzhetu-za-cherven-2020105-perevikonannya-rozpisu-podatkovoyu-i-100-vikonannya-planu-mitniceyu (accessed 15 February 2021).

5. Association of Ukrainian Cities (2020, March 24) Hromady protydiut pandemii COVID-19 [Communities oppose the COVID-19 pandemic]. Retrieved from: http://auc.org.ua/novyna/gromady-protydiyut-pandemiyi-covid-19-dobirka-3 (accessed 15 February 2021).

6. Huliaiev V. O. Poiasniuvalna zapyska do proektu Zakonu Ukrainy «Pro vnesennia zmin do statti 283 Podatkovoho kodeksu Ukrainy (shchodo zvilnennia vid opodatkuvannia zemel u stadii polipshennia yikh stanu)» vid 02.10.2015 № 3211 [Explanatory note to the draft Law of Ukraine "On Amendments to Article 283 of the Tax Code of Ukraine (on exemption from land taxation at the stage of improving their condition)" dated 02.10.2015 No. 3211]. Retrieved from: https://ips.ligazakon.net/ document/GH2H700A (accessed 15 February 2021).

7. Demyanyshyn V. (2007) Teoretychni zasady biudzhetnoi polityky [Theoretical principles of budget policy]. World of Finance, no. 1(10), pp. 19-34.

8. State Statistics Service of Ukraine (2021). Retrieved from: http://www.ukrstat.gov.ua

9. Iefymenko, T. (ed.) (2017) Derzhavni finansy Ukrainy: rozvytok ta upravlinnia zminamy (problemy ekonomichnoi bezpeky) [Public Finance of Ukraine: 
Development and Change Management (Economic Security Problems)]. Kyiv: SESE "The Academy of Financial Management". (in Ukrainian)

10. Zapartina I. V. (2007) Biudzhetnyi mekhanizm ekonomichnoho zrostannia [Budgetary mechanism of economic growth]. Kyiv: Institute of Socio-Economic Strategies. (in Ukrainian)

11. National Bank of Ukraine (2020, December) Zvit pro finansovu stabilnist [Financial Stability Report]. Retrieved from: https://bank.gov.ua/ua/stability/report (accessed 15 February 2021).

12. State Treasury Service of Ukraine (2021) Zvitnist [Reporting]. Retrieved from: https://www.treasury.gov.ua/ua/file-storage/vikonannya-derzhavnogo-byudzhetu

13. Lunina I. O. (ed.) (2017) Konsolidatsiia derzhavnykh finansiv Ukrainy [Consolidation of public finances of Ukraine]. Kyiv: NAS of Ukraine, SI "Institute of Economics and Forecasting of NAS of Ukraine". Retrieved from: http://ief.org.ua/ docs/mg/288.pdf (accessed 15 February 2021).

14. Kuzkin Ye. Yu. (2019) Finansove zabezpechennia fiskalnoho prostoru mistsevoho samovriaduvannia [Consolidation of public finances of Ukraine]. Kharkiv: KhNEU named after S. Kuznets: Technological Center. (in Ukrainian).

15. Ministry of Finance of Ukraine (2021) Makroekonomichnyi ohliad ta prohnoz [Macroeconomic review and forecast] Retrieved from: https://www.mof.gov.ua/ uk/makroogljad (accessed 15 February 2021).

16. Government portal (2020, June 27) MBRR vydilyt Ukraini 350 milioniv dolariv SShA na pidtrymku ekonomichnoho vidnovlennia ta rozvytku [The IBRD will allocate $\$ 350$ million to Ukraine to support economic recovery and development]. Retrieved from: https://mof.gov.ua/uk/news/mbrr_vidilit_ukraini_350 milioniv_dolariv_ssha_na_pidtrimku_ekonomichnogo_vidnovlennia_ta_rozvitku-2224 (accessed 15 February 2021).

17. Government portal (2020, June 11) MVF opryliudnyv tekst Lysta pro namiry ta Memorandumu pro ekonomichnu i finansovu polityku shchodo novoi 18-ty misiachnoi Prohramy Stand-by dlia Ukrainy [IMF publishes text of Letter of Intent and Memorandum of Economic and Financial Policy on new 18-month Stand-by Program for Ukraine]. Retrieved from: https://mof.gov.ua/uk/news/ mvf_opriliudniv_tekst_lista_pro_namiri_ta_memorandumu_pro_ekonomichnu_i_finansovu

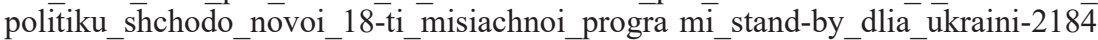
(accessed 15 February $2 \overline{0} 21$ ).

18. Ministry of Finance of Ukraine (2021). Retrieved from: https://www.mof.gov.ua/uk (accessed 15 February 2021).

19. Government portal (2020, April 13) Ministr finansiv Serhii Marchenko: «Pidtrymka MVF - tse harantovana mozhlyvist profinansuvaty usi neobkhidni vydatky, v pershu cherhu sotsialni» [Minister of Finance Serhiy Marchenko: "IMF support is a guaranteed opportunity to finance all necessary expenditures, primarily social"]. Retrieved from: https://mof.gov.ua/uk/news/ministr_ finansiv_sergii_ marchenko_pidtrimka_mvf_-_tse_garantovana_mozhlivist_profinans uvati_usi_neobkhidni_vidatki_v_pershüchergu_sotsialni-2094 (accessed 15 February 2021$)$.

20. Government portal (2020, June18) Minfin zabezpechuie prozorist ta efektyvnist vykorystannia koshtiv Fondu dlia borotby z COVID-19 [The Ministry of 
Finance ensures transparency and efficiency in the use of the Fund's resources to combat COVID-19]. Retrieved from: https://mof.gov.ua/uk/news/minfin_zabezpechuie_prozorist_ta_efektivnist_vikoristannia_koshtiv_fondu_dlia_borotbi_z covid-19-2210 (accessed 15 February 2021).

21. Ministry for Communities and Territories Development of Ukraine (2020) Monitorynh protsesu detsentralizatsii vlady ta reformuvannia mistsevoho samovriaduvannia (stanom na 10 sichnia 2020 r.) [Monitoring of the process of decentralization of power and reform of local self-government (as of January 10, 2020)]. Retrieved from: https://decentralization.gov.ua/uploads/library/file/526/10.01.2020.pdf (accessed 15 February 2021).

22. Muzyka-Stefanchuk O. A. (2011) Meta biudzhetnoi diialnosti u konteksti biudzhetnoi polityky derzhavy [The purpose of budgetary activity in the context of budgetary policy of the state]. Law and Society, iss. 3, pp. 141-146.

23. Association of Ukrainian Cities (2020, April 13) Parlament vrakhuvav propozytsii AMU shchodo zmin do Derzhbiudzhetu-2020 [Parliament takes into account AUC proposals on changes to the State Budget 2020]. Retrieved from: https://www.auc.org.ua/novyna/parlament-vrahuvav-propozyciyi-amu-shchodo-zmin-do-derzhbyudzhetu-2020 (accessed 15 February 2021).

24. Petrukha S., Paliichuk T., Petrukha N. (2020) Mistsevi finansy v umovakh koronakryzy: nova biudzhetna arkhitektonika ta finansova spromozhnist rehuliatsii sektoralnykh i sotsialno-ekonomichnykh protsesi [Local finances in the context of the corona crisis: new budget architecture and financial capacity to regulate sectoral and socio-economic processes]. Finance of Ukraine, no. 12, pp. 83-105. doi: $10.33763 /$ finukr2020.12.083

25. Government portal (2020, June 9) Pidsumky tyzhnia za rezultatamy prohramy "Dostupni kredyty 5-7-9\%»: 51 uhoda na sumu 32,6 mln hrn [Results of the week according to the results of the program "Affordable loans 5-7-9\%": 51 agreements worth UAH 32.6 million]. Retrieved from: https://www.kmu.gov.ua/ news/pidsumki-tizhnya-za-rezultatami-programi-dostupni-krediti-5-7-9-51-ugoda-na-sumu-v-326-mln-grn (accessed 15 February 2021).

26. Verkhovna Rada of Ukraine (2020) Pro vnesennia zmin do deiakykh zakonodavchykh aktiv Ukrainy, spriamovanykh na zapobihannia vynyknenniu $i$ poshyrenniu koronavirusnoi khvoroby (COVID-19 [On Amendments to Certain Legislative Acts of Ukraine Aimed at Preventing the Occurrence and Spread of Coronavirus Disease (COVID-19)] (Act No. 530-IX, March 17). Retrieved from: https://zakon.rada.gov.ua/laws/show/530-IX (accessed 15 February 2021).

27. Verkhovna Rada of Ukraine (2020) Pro vnesennia zmin do deiakykh zakonodavchykh aktiv Ukrainy, spriamovanykh na zabezpechennia dodatkovykh sotsialnykh ta ekonomichnykh harantii u zviazku z poshyrenniam koronavirusnoi khvoroby (COVID-19) [On Amendments to Certain Legislative Acts of Ukraine Aimed at Providing Additional Social and Economic Guarantees in Connection with the Spread of Coronavirus (COVID-19)] (Act No. 540-IX, March 30). Retrieved from: https://zakon.rada.gov.ua/laws/show/540-20\#Text (accessed 15 February 2021).

28. Verkhovna Rada of Ukraine (2020) Pro vnesennia zmin do Zakonu Ukrainy «Pro Derzhavnyi biudzhet Ukrainy na 2020 rik» [On Amendments to 
the Law of Ukraine "On the State Budget of Ukraine for 2020"] (Act No. 553-IX, April 13). Retrieved from: https://zakon.rada.gov.ua/laws/show/553-IX (accessed 15 February 2021).

29. Verkhovna Rada of Ukraine (2020) Pro vnesennia zmin do Podatkovoho kodeksu Ukrainy ta inshykh zakoniv Ukrainy shchodo pidtrymky platnykiv podatkiv na period zdiisnennia zakhodiv, spriamovanykh na zapobihannia vynyknenniu $i$ poshyrenniu koronavirusnoi khvoroby (COVID-19) [On Amendments to the Tax Code of Ukraine and Other Laws of Ukraine Concerning Support to Taxpayers for the Period of Implementing Measures Aimed at Preventing the Occurrence and Spread of Coronavirus Disease (COVID-19)] (Act No. 533-IX, March 17). Retrieved from: https://zakon.rada.gov.ua/laws/show/533-20 (accessed 15 February 2021).

30. Verkhovna Rada of Ukraine (2020) Pro vnesennia zmin do Podatkovoho kodeksu Ukrainy ta inshykh zakoniv Ukrainy shchodo dodatkovoi pidtrymky platnykiv podatkiv na period zdiisnennia zakhodiv, spriamovanykh na zapobihannia vynyknenniu i poshyrenniu koronavirusnoi khvoroby (COVID-19) [On Amendments to the Tax Code of Ukraine and Other Laws of Ukraine Concerning Additional Support to Taxpayers for the Period of Implementing Measures Aimed at Preventing the Occurrence and Spread of Coronavirus Disease (COVID-19)] (Act No. 591-IX, May 13). Retrieved from: https://zakon.rada.gov.ua/laws/show/591-20\#Text. (accessed 15 February 2021).

31. Cabinet of Ministers of Ukraine (2020) Pro vnesennia zmin do Poriadku nadannia derzhavnoi pidtrymky subiektam mikropidpryiemnytstva ta maloho pidpryiemnytstva [On amendments to the Procedure for providing state support to micro and small businesses] (Decree No. 283, April 15). Retrieved from: https://zakon.rada.gov.ua/ laws/show/283-2020-\%D0\%BF\#Text (accessed 15 February 2021).

32. Cabinet of Ministers of Ukraine (2019) Pro vnesennia zmin do postanovy Kabinetu Ministriv Ukrainy vid 15 travnia 2019 r. \# 555 [On amendments to the resolution of the Cabinet of Ministers of Ukraine of May 15, 2019 No. 555] (Decree No. 253, March 29). Retrieved from: https:/www.kmu.gov.ua/npas/pro-vnesennya-zmin-do-postanovi-kabinm2903020etu-ministriv-ukrayini-vid-15-travnya2019-r-555 (accessed 15 February 2021).

33. Cabinet of Ministers of Ukraine (2020) Pro zatverdzhennia Derzhavnoi stratehii rehionalnoho rozvytku na 2021-2027 roky [On approval of the State Strategy for Regional Development for 2021-2027] (Decree No. 695, August 5). Retrieved from: https://zakon.rada.gov.ua/laws/show/695-2020-\%D0\%BF\#Text (accessed 15 February 2021).

34. Cabinet of Ministers of Ukraine (2020) Pro zatverdzhennia Derzhavnoi stratehii rehionalnoho rozvytku na period do 2020 roku [On approval of the State Strategy for Regional Development until 2020] (Decree No. 385, August 6). Retrieved from: https://zakon.rada.gov.ua/laws/show/385-2014-\%D0\%BF\#Text (accessed 15 February 2021).

35. Cabinet of Ministers of Ukraine (2015) Pro skhvalennia Kontseptsii rozvytku silskykh terytorii [About approval of the Concept of development of rural territories] (Decree No. 995-r, September 23). Retrieved from: https://zakon.rada.gov.ua/laws/ show/995-2015-\%D1\%80\#n8 (accessed 15 February 2021). 
36. Verkhovna Rada of Ukraine (2020) Proekt Zakonu pro vnesennia zmin do Biudzhetnoho kodeksu Ukrainy shchodo zastosuvannia formulnoho rozpodilu subventsii na dorohy [Draft Law on Amendments to the Budget Code of Ukraine on the Application of the Formulad Subdivision of Roads] (No. 3919, July 22). Retrieved from: http://w1.c1.rada.gov.ua/pls/zweb2/webproc4_1?pf3511=69585 (accessed 15 February 2021).

37. Verkhovna Rada of Ukraine (2020) Proekt Zakonu pro vnesennia zmin do Zakonu Ukrainy "Pro Derzhavnyi biudzhet Ukrainy na 2020 rik" [Draft Law on Amendments to the Law of Ukraine "On the State Budget of Ukraine for 2020"] (No. 3776, July 2). Retrieved from: http://w1.c1.rada.gov.ua/pls/zweb2/webproc4_1?pf3511=69334 (accessed 15 February 2021).

38. Verkhovna Rada of Ukraine (2020) Proekt Zakonu pro vnesennia zmin do Podatkovoho kodeksu Ukrainy ta deiakykh inshykh zakoniv Ukrainy shchodo zakhodiv stymuliuvannia ekonomiky Ukrainy vid вid 15.07.2020 № 3848 [Draft Law on Amendments to the Tax Code of Ukraine and Some Other Laws of Ukraine on Measures to Stimulate the Economy of Ukraine] (No. 3848, July 15). Retrieved from: http://w1.c1.rada.gov.ua/pls/zweb2/webproc4_1?pf3511=69478 (accessed 15 February 2021).

39. Verkhovna Rada of Ukraine (2020) Proekt Zakonu pro osnovni zasady derzhavnoi ahrarnoi polityky ta derzhavnoi polityky silskoho rozvytku [Draft Law on Basic Principles of State Agrarian Policy and State Policy of Rural Development] (No. 9162, October 4). Retrieved from: http://w1.c1.rada.gov.ua/pls/zweb2/webproc4_1?pf3511=64742 (accessed 15 February 2021).

40. State Statistics Service of Ukraine (2019) Rehiony Ukrainy (statystychnyi zbirnyk) [Regions of Ukraine (statistical collection)]. Kyiv. Retrieved from: http://www.ukrstat.gov.ua/druk/publicat/kat_u/2019/zb/12/zb_ru1ch2019.pdf (accessed 15 February 2021).

41. European Business Association (2020, May 27) Tretyna malykh pidpryiemtsiv vtratyly bilshe $50 \%$ dokhodiv [One third of small entrepreneurs lost more than $50 \%$ of income]. Retrieved from: https://eba.com.ua/tretyna-malyh-pidpryyemtsiv-vtratyly-bilshe-50-dohodiv/ (accessed 15 February 2021).

42. Government portal (2020, May 1) U kvitni do derzhavnoho biudzhetu nadiishlo ponad $90 \mathrm{mlrd}$ hrn. [In April, the state budget received over UAH 90 billion]. Retrieved from: https://www.kmu.gov.ua/news/u-kvitni-do-derzhavnogo-byudzhetu-nadijshlo-ponad-90-mlrd-grn

43. Government portal (2020, June 1) U travni $2020 \mathrm{r}$. do zahalnoho fondu derzhbiudzhetu nadiishlo 63,9 mlrd hrn - rozpys vykonano na 100\% [In May 2020, the general fund of the state budget received UAH 63.9 billion - the painting was completed by $100 \%$ ]. Retrieved from: https://mof.gov.ua/uk/news/minfin_u travni_2020_roku_do_zagalnogo_fondu_derzhbiudzhetu_nadiishlo_639_mlrd_grn_- rozpis_vikonano_na_100-2167 (accessed 15 February 2021).

$\overline{4} \overline{4}$. National Institute for Strategic Studies (2020) Ukraina - 2030. Stratehiia zminy maibutnoho [Ukraine - 2030. Strategy for changing the future]. Retrieved from: https://niss.gov.ua/sites/default/files/2020-12/ukraine-2030-1.pdf (accessed 15 February 2021). 
45. National Institute for Strategic Studies (2020) Ukraina - 2030. Stratehiia zminy maibutnoho [Ukraine - 2030. Strategy for changing the future]. Retrieved from: https://niss.gov.ua/sites/default/files/2020-12/ukraine-2030-1.pdf (accessed 15 February 2021).

46. Government portal (2020, June 10) Ukraina otrymala 500 mln yevro makrofinansovoi dopomohy YeS [Ukraine has received $€ 500$ million in EU macro-financial assistance]. Retrieved from: https://mof.gov.ua/uk/news/ukraina_otrimala_500 mln ievro makrofinansovoi dopomogi ies-2183 (accessed 15 February 2021).

$\overline{4}$. National Institute for Strategic Studies (2020) Ukraina pislia koronakryzy shliakh oduzhannia [Ukraine after the corona crisis is a way of recovery]. Kyiv: NISS. Retrieved from: https://niss.gov.ua/sites/default/files/2020-11/ukraina-pislya-koronakrizi_sait.pdf (accessed 15 February 2021).

48. Ministry for Economic Development, Trade and Agriculture of Ukraine (2020, April) Ukraina u 2020-2021 rokakh: naslidky pandemii. Konsensus-prohnoz [Ukraine in 2020-2021: consequences of the pandemic. Consensus forecast]. Retrieved from: https://www.me.gov.ua/Documents/Download?id=4bbc60fa-b4f74fb9-a335-b60a2ac0ac03 (accessed 15 February 2021).

49. Government portal (2020, May 27) Uriad predstavyv Prohramu stymuliuvannia ekonomiky dlia podolannia naslidkiv COVID-19 [The government has introduced the Economic Incentive Program to overcome the effects of COVID-19]. Retrieved from: https://www.kmu.gov.ua/news/uryad-predstaviv-programu-stimulyuvannya-ekonomiki-dlya-podolannya-naslidkiv-covid-19 (accessed 15 February 2021).

50. Fitch Ratings (2020, April 2) Deep Global Recession in 2020 as Coronavirus Crisis Escalates. Retrieved from: https://www.fitchratings.com/research/sovereigns/deep-global-recession-in-2020-as-coronavirus-crisis-escalates-02-04-2020 (accessed 15 February 2021).

51. Petrukha S., Paliichuk T., Alekseienko N. (2020) Budgetary policy and budgetary regulation of economic dynamics under the corona crisis conditions. Ukraine in the context of global and national modern servisation processes and digital economy. Praha, Czech Republic: OKTAN PRINT, pp. 113-143.

52. Petrukha S., Paliichuk T. (2019) Tax decentralization: theory, methodology and practice. Management mechanisms and development strategies of economic entities in conditions of institutional transformations of the global environment (in 2 vols.). Riga: "Landmark" SIA, pp. 288-304.

53. IMF (2020, April) World Economic Outlook: The Great Lockdown. Retrieved from: https://www.imf.org/en/Publications/WEO/Issues/2020/04/14/ weo-april-2020 (accessed 15 February 2021). 